Article

\title{
Stay or Leave? Arctic Youth Prospects and Sustainable Futures of the Russian Arctic Communities
}

\author{
Marya Rozanova-Smith 1,2,3 \\ 1 Department of Geography, Elliott School of International Affairs, The George Washington University, \\ Washington, DC 20009, USA; marya_rozanova@gwu.edu \\ 2 ARCTICenter, University of Northern Iowa, Cedar Falls, IA 50614, USA \\ 3 Department of Social and Human Sciences, Russian State Hydrometeorological University, \\ Saint Petersburg 192007, Russia
}

Citation: Rozanova-Smith, M. Stay or Leave? Arctic Youth Prospects and Sustainable Futures of the Russian Arctic Communities. Sustainability 2021, 13, 12058. https://doi.org/ $10.3390 /$ su132112058

Academic Editors: Gail Fondahl, Grete K. Hovelsrud, Tero Mustonen and Stephanie Pfirman

Received: 20 July 2021

Accepted: 25 October 2021

Published: 1 November 2021

Publisher's Note: MDPI stays neutral with regard to jurisdictional claims in published maps and institutional affiliations.

Copyright: (C) 2021 by the author. Licensee MDPI, Basel, Switzerland. This article is an open access article distributed under the terms and conditions of the Creative Commons Attribution (CC BY) license (https:/ / creativecommons.org/licenses/by/ $4.0 /)$.

\begin{abstract}
Based on quantitative and qualitative analysis, this paper attempts to answer a research question that is critical for many Arctic communities: "What makes local youth want to leave?" Using the Russian Arctic cities of Naryan-Mar, Salekhard, and Novy Urengoy (Nenets and Yamalo-Nenets regions) as case studies, this article explores how local youth contribute to social sustainability and define the futures of their Arctic cities. The study identifies new variables relevant to the youth cohort built on the Urban Sustainability Index and social sustainability model. Based on 400+ questionnaires and interviews with Indigenous and non-Indigenous youth, education professionals, and public officials, this study looks at the youth's educational and professional strategies, social activities and cultural consumption, migration patterns, and civic engagement in a broader context. This article also discusses how local youth feel disempowered in building their futures and highlights the importance of access to educational opportunities and wider career choices in the Arctic.
\end{abstract}

Keywords: Arctic; youth; Indigenous youth; migration; social sustainability; Russia

\section{Introduction}

Fostering urban sustainability in the Arctic is one of the most pressing and challenging tasks in the rapidly changing Circumpolar North, and it will be for many years to come. In the Russian Arctic, since the beginning of its active exploration in the 20th century, rapid resource-based industrialization has resulted in an unprecedented rate and scale of urbanization, which has turned the remote Arctic regions into 'hot spots' of human and social mobility. Today, the highly industrialized areas of the Russian Arctic are reaching rates of urbanization comparable to the Russian average $(74.66 \%)$, and the Yamalo-Nenets (YaNAO) and Nenets (NAO) regions (83.95\% and 73.76\%, respectively) are no exception.

Developed in the Soviet times as the regional urban centers of NAO and YaNAO, Naryan-Mar (1935), Salekhard (1938), and Novy Urengoy (1975) (Figure 1) were primarily designated to drive the exploitation of natural resources and soon became symbols of Soviet pride through heroic Arctic conquest. In the process, these cities became magnets for young professionals both dreaming of new feats and searching for upward social mobility and economic benefits. Cultivated over time, a diverse range of administrative functions failed to make these cities' economies diversified enough to sustain themselves in the situation of natural resource depletion or lower demand on the global market in times of substantial transition to renewable energy [1]. Today, both study regions are showcases of Arctic economies that are still dominated by natural resource industries, the government sector, and traditional subsistence activities [2]. 


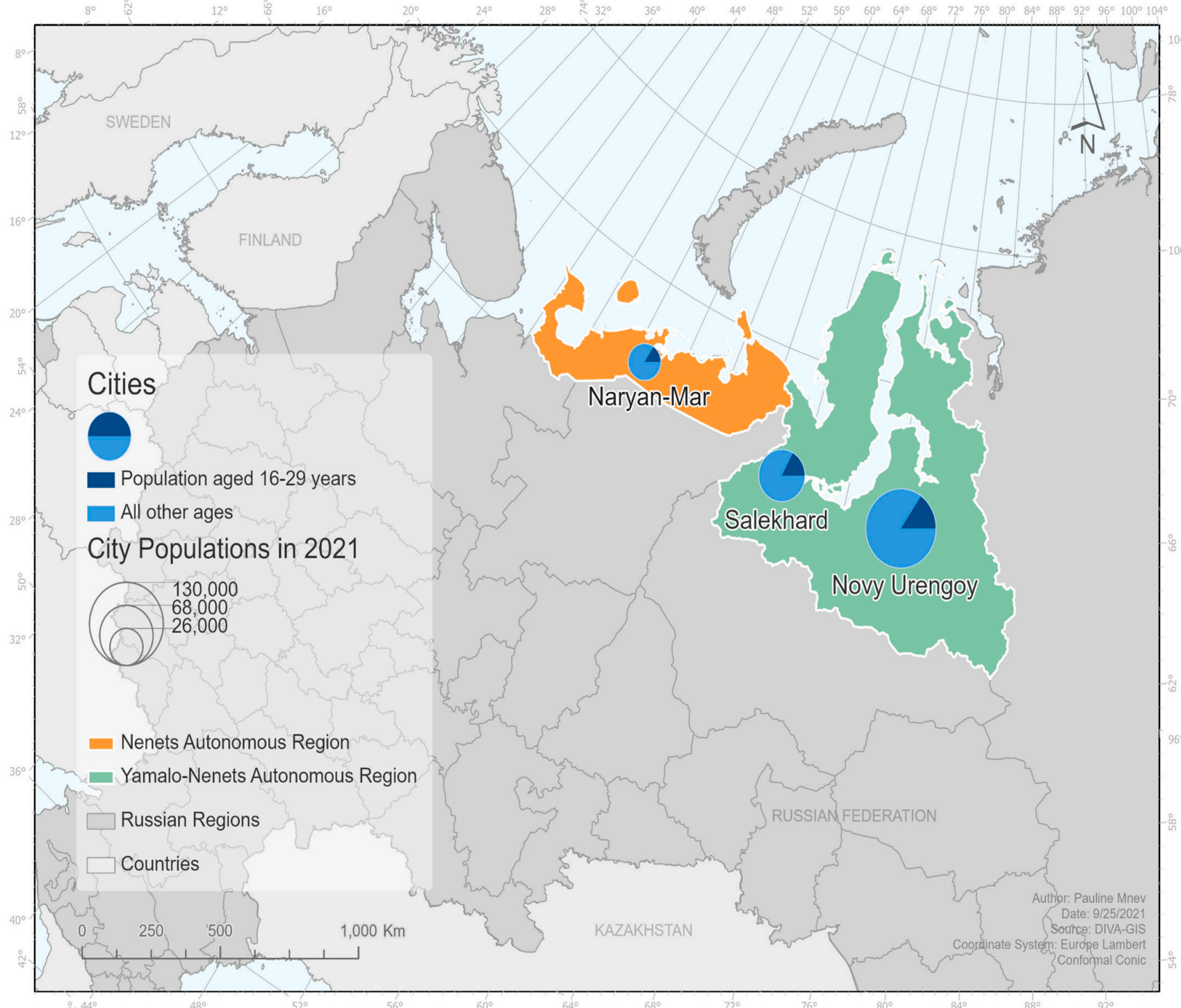

Figure 1. Map of the study sites showing the share of the city population aged 16-29 years. Author's calculations based on [3].

Rich in reserves of hydrocarbon raw materials, the local economies of NAO and YaNAO are heavily reliant on oil or gas extraction. NAO's estimated natural resources are 1 billion tons of oil and 500 billion cubic meters of gas. In recent years, $80-85 \%$ of the regional budget revenue came from taxes levied on oil companies. However, $84 \%$ of the tax revenue goes to the federal budget, and Naryan-Mar has limited resources for socioeconomic development and innovative practices [4,5]. YaNAO houses approximately $60 \%$ of Russia's gas reserves and $14 \%$ of its oil reserves, making it a highly attractive location for investments and development. The region is experiencing intensive economic growth. It is introducing mega-projects in the gas industry (with over $80 \%$ of all of Russia's natural gas production and over $60 \%$ of all-Russian LNG production), experiencing increases in urban infrastructure, and aggressively expanding transportation systems. Today, YaNAO is running one of the world's largest LNG projects. Related to oil and gas transportation, Yamal has one of the largest gas pipeline systems in the Circumpolar North. It is also one of the federal budget "donor regions", providing more than $10 \%$ of Russia's federal budget revenues [6]. Both the NAO and YaNAO regions are home to Indigenous Peoples pursuing a traditional way of life, and ambitious development projects are often confronted with intensified competition for land use with an Indigenous subsistence economy [7]. 
The three Arctic cities explored in this paper are different yet indicative cases of the overreliance on natural resource-based regional economies in the Arctic. Naryan-Mar and Salekhard-regional capitals (administrative centers) with regional legislative institutionsare located on Indigenous ancestral lands and are home to the Arctic Indigenous Peoples. Naryan-Mar's population of 25,536 (2021) is heavily dominated by ethnic Russians, with the second-largest group being Indigenous Peoples (Nenets and Komi (14.01\%)) [8]. In Salekhard, with a population of 51,186 (2021), there are strong trends towards greater diversity. Among the numerous top ethnic groups are Russians, Tatars, Ukrainians, and Indigenous Peoples of the North (8.47\%), including Nenets, Khanty, and Komi-Zyrayane [9]. The most populated city Novy Urengoy (118,115 residents, 2021), unofficially called the "Gas Capital of Russia", is a truly ethnically and culturally diverse YaNAO industrial capital with new strong trends towards even greater ethnic, cultural, and religious complexity $[9,10]$. The exception here is the absence of Arctic Indigenous Peoples: Only a few Indigenous families have settled in Novy Urengoy as for centuries Nenets People have viewed this location as "The Land of Fire", a deathtrap.

Today, NAO and YaNAO hold the top two positions on the list of Russian regional GDP per capita [11], which is approximately ten (!) times higher than the national average [6]. At the same time, both NAO and YaNAO are the only regions in Russia that do not have universities, and NAO has no scientific research centers. Their absence not only presents a clear barrier for the emergence of a modern knowledge-based economy in these resource bases, but can also greatly affect the local youth and their education, career, and life choices.

Based on quantitative and qualitative analysis, this paper attempts to answer the critical research questions: "What makes local urban youth in the two wealthiest regions of Russia-the Nenets and Yamal Nenets regions-want to leave permanently?" and "How does this influence broader-scale patterns of social sustainable development in the Arctic?"

Assessment of multiple risks associated with regional economies, environment, and local communities within the theoretical framework of sustainability is gaining more attention in science and recognition in policymaking across Arctic regions. Despite the initial predominant focus on economic sustainability aspects (this vision of sustainability as economic sustainability is still prevalent in official documents in the public administrative sphere in Russia [12] (Decree of Administration of Naryan-Mar N 422 (31 March 2015) “Ob utverzhdenii plana pervoocherednykh meropriyatiy po obespecheniyu ustoychivogo razvitiya ekonomiki i sotsial'noy stabil'nosti v MO "Gorodskoy okrug" Gorod Naryan-Mar [“On approval of the Plan of Priority Measures to Ensure Sustainable Economic Development and Social Stability in the City of Naryan-Mar"]; Strategy of Socioeconomic Development of Naryan-Mar till 2030; Strategy of Socioeconomic Development of Salekhard till 2030; Strategy of Socioeconomic Development of Novy Urengoy till 2030); see also: [13]) and environmental sustainability aspects, studies are now shifting towards a more comprehensive approach including a social component [12-16]. The concept of 'social sustainability,' a relatively new conceptual analysis area in wide-ranging sustainability, is firmly placed at the forefront of emerging Arctic urban sustainability studies [12,13,17-19].

The conceptualization of social sustainability is problematic [20] due to its multifaceted complexity and dynamism. Out of the myriad of employed definitions, in this research, 'social sustainability' is presented through the prism of a future-oriented construct of "sustainable urban communities", which are broadly defined as "places where people want to live and work, now and in the future" [21] (p. 6).

In Russia, academic and public discussions conceptualize the future of the North and its urban areas generally through the prisms of applied economic theory [22] with elements of instrumental rationality, economic geography [23], or allusions to a Soviet historical legacy of Arctic exploration and post-Soviet narratives about the Arctic and its role in national identity and pride as, e.g., described in [24]. To a lesser extent, these discussions apply concepts of social psychology such as belonging and emotional attachment to place and community $[13,23]$. 
Often overlooked in sustainability studies [25], youth need a special focus of attention in the future-focused approach as drivers of economic change and contributors to local communities' development. This study identifies the following key components of social sustainability $[20,26,27]$ as especially relevant to urban youth of various age cohorts between 14 and 35 years old in the three Polar cities of Naryan-Mar, Salekhard, and Novy Urengoy:

- Opportunities for education and training (including well-performing higher education institutions).

- The scale of migration and its patterns.

- A wide range of high-quality jobs available for local youth.

- Opportunities for cultural, sports, and leisure activities.

- Social integration and social contribution (community and voluntary sector).

To measure these components, a system of youth-relevant indicators has been developed. Primarily based on ISO 37120 (Sustainable cities and communities-Indicators for city services and quality of life) (ISO, 2018) and the findings of the Program for International Research and Education project "Promoting Urban Sustainability in the Arctic" (PIRE Project) (PIRE), this paper also introduces new variables (e.g., entertainment and civic activities) (see Appendix A, Table A1). Due to limitations on data availability, other components of social sustainability, such as "Feeling of belonging (emotional attachment) to a place and community", "Affordable housing", and "Political engagement and empowerment" are not a part of analysis in this paper.

Among the selected social sustainability components, local youth migration is "one of the main drivers of changes in the urban landscape" [28] (p. 108). In many ways, other components can be described as underlying determinants of migration trends that affect migration flows, particularly youth out-migration.

In Arctic social studies, youth have been a special focus for decades [29-36]. Despite an increasing research interest in Russian Arctic youth's portrait and migration motivations [37-41], our knowledge in this sphere is still scarce. This limits our understanding of the factors contributing to social sustainability in the Arctic regions for the years ahead. In an attempt to fill some knowledge gaps, this paper presents Arctic youth's voices on their educational and career strategies, migration patterns, and future prospects.

\section{Materials and Methods}

\subsection{Rationale for the Selection of Study Sites}

This study uses the three Arctic cities of Naryan-Mar, Salekhard, and Novy Urengoy in NAO and YaNAO as case studies that are indicative of many Circumpolar regions. Based on functional classification, the focal cities represent two major models in the Arctic: administrative centers (Naryan-Mar and Salekhard) with the dominance of the government sector in the economy, and an industrial center (Novy Urengoy) with an economy based on natural resource extraction. In addition, $\mathrm{NAO}$ and YaNAO are the two wealthiest major economic centers among the Russian regions (GDP per capita), which helps to shed light on challenges and opportunities that Arctic youth can experience in other affluent Circumpolar regions.

\subsection{Design of Selected Social Sustainability Indicators}

As part of a contribution to studies on Arctic urban sustainability, this research applies metrics created by ISO 37120 [42], which have been modified to study youth. Aimed at finding some gaps in the system of ISO indicators related to the North's specific features, this novel approach includes analysis of variables that are likely to affect the future social sustainability of the Arctic urban communities. As presented in Appendix A (Table A1), the selected variables include relevant values covered by ISO and complementary variables explicitly designed for urban youth. Among them are demographics, education, economics, culture, sports, entertainment, civil society, and political empowerment indicators. 


\subsection{Methods}

Data for indicators were collected from primary and secondary sources of information and included regional and municipal statistical datasets (Rosstat), ISO 37120 developed by the PIRE project's experts, reports from government bodies, municipal development plans, and regional strategies, and municipal reports.

The quantitative analysis of indicators complements qualitative findings based on informal surveys (questionnaires) that included young people, education and labor market professionals, interviews with local officials and Indigenous leaders, and participant observations undertaken during the author's qualitative research in the focal study areas.

In this study, questionnaires were chosen as the most efficient survey method as they allow for information to be gathered from large audiences and for results to be compared. They can also be used in future research to measure change, as well as preserving the anonymity of survey participants. Overall, 406 participants contributed to this study in the form of informal surveys (questionnaires) and interviews. The youth survey enrolled local young people -258 high school and vocational college students, including predominantly Indigenous high school students from the boarding school in NAO (Naryan-Mar) (50 respondents); high school students in NAO (Naryan-Mar) (36 respondents); high school students in YaNAO (Salekhard and Novy Urengoy) (84 respondents); and vocational college students in NAO (Naryan-Mar) (40 respondents) and YaNAO (Salekhard) (48 respondents). Questionnaires addressed the following topics: youth's life strategies (where they see their future); education and career strategies (who they want to be, where they are planning to proceed with their education, where they want to work); advantages and barriers to professional/personal growth in their home regions; students' networks outside their cities (friends and relatives); and students' leisure time and hobbies. To ensure that the study posed no risks to the participants, the questionnaires did not include the sensitive topic of political engagement and empowerment.

To understand the broader context, provide additional insights, and better understand local labor market conditions and challenges for local youth, 132 education and employment services professionals (52 in YaNAO and 80 in NAO) were surveyed. The questionnaires were focused on the most pressing issues that young city-dwellers face in the NAO and YaNAO regions, including education and career opportunities as well as local labor market conditions. All surveys were carried out face to face. They contained both open-ended and closed questions; the latter also included a continuous rating scale to measure the strength of attitudes. In addition, sixteen in-depth, semi-structured, in-person interviews about local labor market conditions and opportunities for the local youth were conducted with regional officials and Indigenous leaders who live and work in the focal cities of NAO and YaNAO. This method was preferred as it is the most effective method for qualitative research for understanding the societal context and exploring respondents ${ }^{\prime}$ opinions and experiences. Also, this method was chosen because of its practicality, as it enables researchers to reach this focus group. Initial interview respondents were selected through personal contacts, and the interviewee pool was developed using the snowball sampling method. All the interview participants were notified about the research and its objectives, and their consent for participation was received. Interviews were analyzed in detail primarily through thematic analysis.

\section{Results}

This section is organized in the following way. Each thematic part first presents available statistical information and analytical data in the broader context to examine key components of social (socioeconomic) sustainability primarily based on ISO 37120 in the three focal Polar cities, and then complements and links them to results of surveys during the author's qualitative fieldwork. The presented complementary qualitative findings voicing Arctic youth's vision of their education, career, life strategies, leisure time activities, and social connections support the quantitative analysis of social sustainability components and indicators of urban sustainability relevant to the Arctic youth. 


\subsection{Educational and Labor Market Opportunities for Local Youth: General Overview}

Among the important common characteristics of the Northern cities of Naryan-Mar, Salekhard, and Novy Urengoy that to a certain extent determine both the local youth's education and career paths and life strategizing are: (1) no higher education institutions, and (2) a dominant natural resource-reliant economy that creates a highly competitive labor market for high-, semi-, and low- skilled workers.

\subsubsection{Paradox: No universities vs. highest rates of university degrees among residents}

Nowadays, NAO and YaNAO are the only two regions in the Russian Federation that do not have higher education institutions. By not investing in human capital in these "donor regions" through the higher education system, the federal government de facto forces employers to bring in well-trained crème de la crème professionals from elsewhere. Correlating with ISO indicator 6.6 "Number of higher education degrees per 100,000 population" (Appendix A, Table A1), available data on the share of the employed population aged 25-64 with higher education show that NAO and YaNAO are experiencing an increasing influx of highly skilled labor (Figure 2).

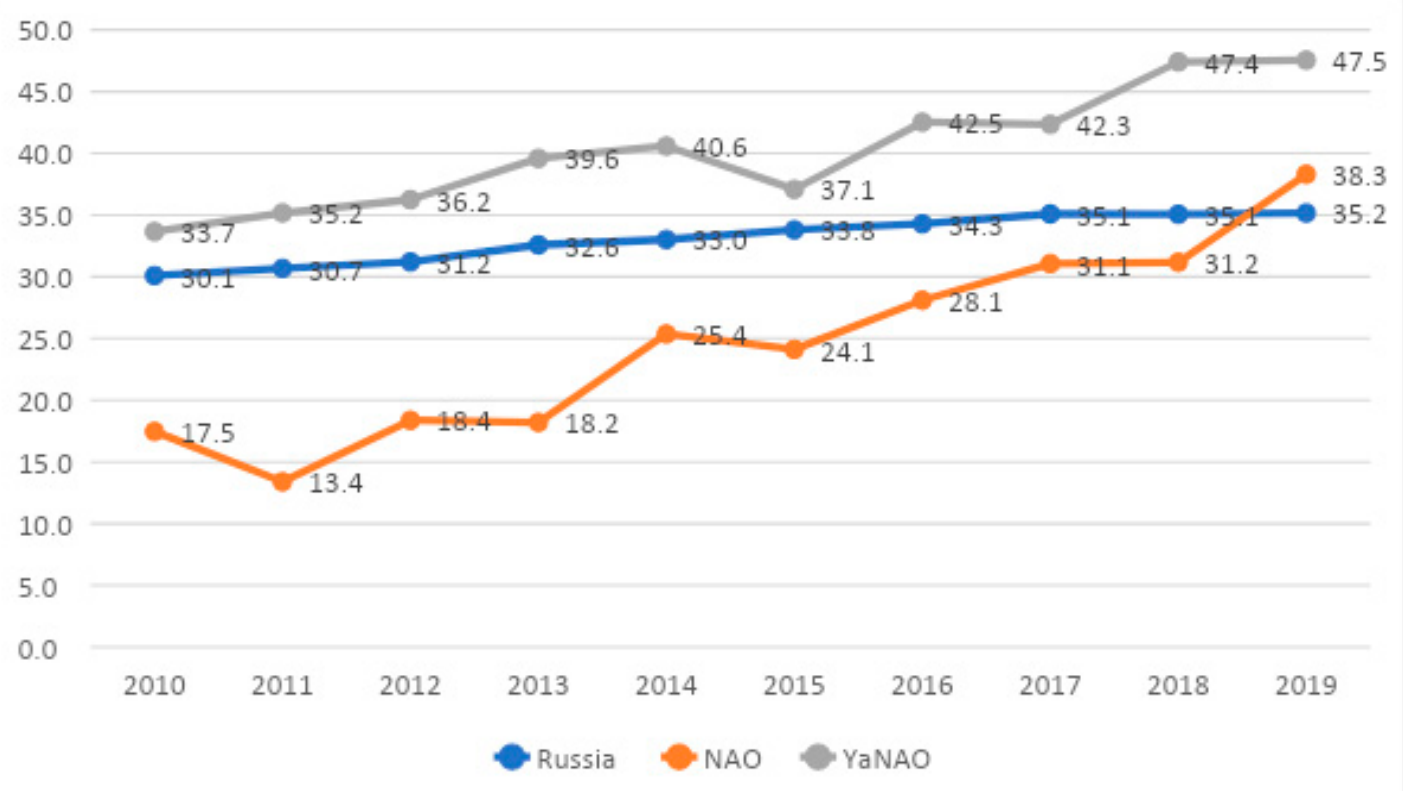

Figure 2. Dynamics of changing share of the employed population aged 25-64 with higher education (in \%). Author's calculations based on Federal State Statistics Service of the Russian Federation (Rosstat), 2020 (annual sample surveys of the labor force).

This situation illustrates one of many Arctic paradoxes: two regions with no university education services have the highest university degree rates among residents in the country. As a result of this paradox, local high school and vocational college students are most likely to consider educational migration as the only way out (see survey results, Section 3.2 below). Often this decision to leave is a point of no return. Similarly to many other Circumpolar regions, return migration remains low: "leaving a region in pursuit of higher education increases the chance of a student starting a family [and/or new career pathauthor's] close to their place of education, which can decrease the likelihood of eventually returning to their region of origin" [43] (p. 183).

Although the Russian official statistics do not provide data on "city-to-city" and return migration [44] and accurate numbers are unavailable, webometric research findings by Moscow State University confirm the general trend: young people do not return to their Arctic home cities with university diplomas [45] and are likely to settle elsewhere in better climatic conditions and with a wider range of professional development op- 
portunities. These results also concur with findings from surveys among education and employment professionals ( $72 \%$ described youth's permanent out-migration as a strong ongoing trend) and the author's interviews with local officials who recognize these processes as a serious concern.

From a historical perspective, youth exodus, primarily non-Indigenous, from the Russian Arctic is not a new phenomenon [46-49] in the dynamic and continuously changing Arctic, but rather a "continuation of a family cycle, migration to the North-migration from the North, which takes between one and three generations to complete" [50] (p. 61). However, the scale of today's ongoing youth educational out-migration and the exacerbating trend of youth reduction in the working-age cohort signal an ongoing demographic shift (Figure 3) and future labor supply challenges. In all focal cities' official Strategies of Socioeconomic Development until 2030, youth exodus is described as a clear threat to local economy and a challenge for city youth-oriented policies [51-53].

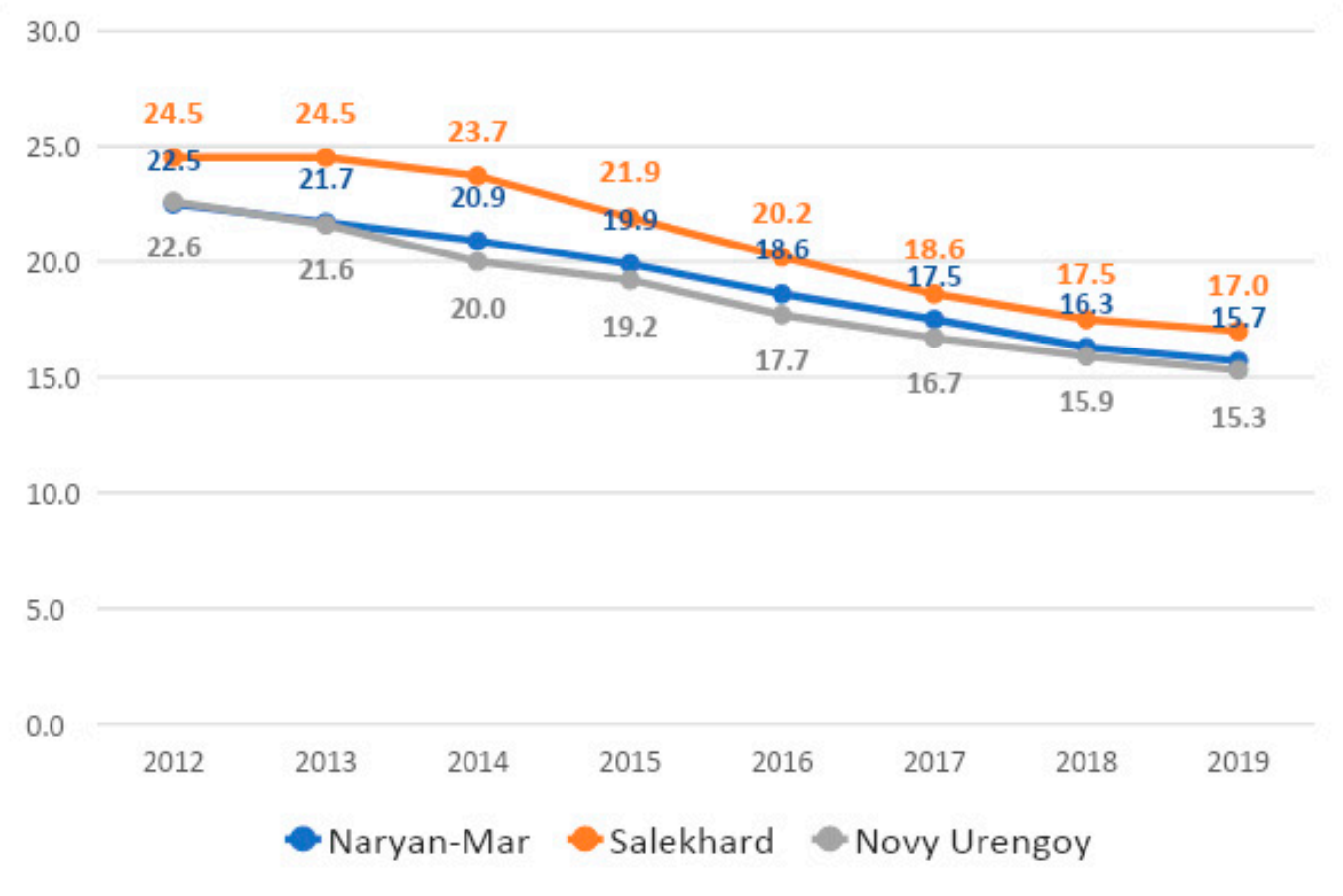

Figure 3. Dynamics of changing share of young adults in the 16-29-year-old cohort in Naryan-Mar, Salekhard, and Novy Urengoy, 2012-2019 (in \%). Author's calculations based on [3].

Despite ongoing negative demographic trends, there is still no indication of a strong deficit of young people of working age for local economies. Out-migration of young adults meets a counter-trend-both Northern regions (urban centers) turned into magnets receiving a surplus of young people of working age (predominantly between 20 and 30), both high- and low-skilled professionals $[28,54](3)$.

\subsubsection{Arctic Labor Market and Left behind Locals}

The economies of NAO and YaNAO are heavily dominated by natural resource industries, the government sector, and traditional subsistence activities [2]. Depending on the city's central role as an industrial or administrative center, the most lucrative sphere of employment with higher wage rates in focal urban areas remains oil and gas companies (Novy Urengoy) and the government sector (Naryan-Mar and Salekhard) [5,6]. Overall, in NAO, the oil sector generates 8700 jobs (25\% of the total NAO labor resources) [5], and the government of the regional capital of Naryan-Mar is the top employer (17\% of total city employees). In YaNAO, the oil and gas sector generates $27 \%$ of the total jobs [6]; in Novy Urengoy, the gas capital of YaNAO, the fuel and energy complex employs $40.7 \%$ of 
the total labor resources [6], while in Salekhard, the government is one of the top sectors of employment with $27 \%$ of total city employees [52]. The question remains as to who can obtain high-quality jobs in those key economic sectors.

As a long-established and globally widespread practice in extraction industries [55-59], primarily oil and gas in these regions, corporations heavily rely on an "imported" temporary and fly-in, fly-out (FIFO) workforce and are reluctant to hire locals outside of a narrow range of qualified professionals specially trained for their needs or unskilled workers for miscellaneous services (e.g., cleaning, catering, etc.). A significant gap is also diagnosed between the level of remuneration in the extractive industries and other sectors of the economy. For instance, in NAO, the average monthly salary in extractive industries is more than 100 thousand rubles, while in other sectors of the economy, it is about 50-70 thousand rubles [53].

In addition, the regional labor markets are also saturated with newcomers from Russia's northwestern and central regions and the North Caucasus (predominantly from Dagestan and Chechen Republic) [60], who intend to stay for prolonged periods of time, as well as seasonal labor migrants from 'near-abroad' (primarily from the Central Asian countries of Kyrgyzstan, Uzbekistan, and Tajikistan), and diverse labor migrants from Azerbaijan $[10,61,62]$. It is plausible that competition for jobs between semi- and low-skilled young locals and newcomers is so intense that the former ones who have not left their hometowns for better education and training perceive themselves as "left behind" vulnerable Northerners. For instance, in Salekhard, the survey presented in the Strategy of Socioeconomic Development of Salekhard until 2030 indicates a high level of vulnerability among low / semi-skilled workers: $100 \%$ of respondents without higher degrees expressed serious concerns about poverty and unemployment; in comparison, only 56\% of respondents with higher degrees were concerned about poverty, and 49\% about unemployment.

An effort to address the lack of available high-quality jobs for young residents was initiated in NAO in 2016. The authorities introduced quotas for all companies with more than 50 employees working in the region to hire local residents [63]. However, the implementation of this initiative is problematic: quotas, even when "formally" filled, do not guarantee the locals prospective and well-paid positions.

Top oil and gas extraction companies-Rosneft (NAO) and Lukoil, Novatek, and Gazprom (YaNAO) - have invested in youth human capital by supporting educational initiatives, yet the outcomes are very modest and do not make any difference in the local labor market in the broader context of Arctic social sustainability. For instance, under an NAO administration initiative, in 2012, Rosneft launched an educational project of smallnumbered high school classes with intense specialized training for the best high school students (10th-11th grade) in the region. Since 2012, out of almost 100 graduates from Rosneft classes, only one has been employed in this oil company, and five students have got scholarships at the Ukhta State Technical University in the neighboring Komi region [64]. In Salekhard and Novy Urengoy, similar educational initiatives are being implemented by Gazprom (since 2010), Novatek (since 2018), and Lukoil (since 2020). In addition to these specially organized high school classes, Gazprom also runs a company-owned Vocational School in Novy Urengoy and provides employment opportunities to some graduates for positions that do not require university diplomas. Although neither the Ministry of Education of YaNAO nor Gazprom publish information about graduates' employment results and career paths, based on the results of interviews and general observations, one can suggest they are also not impressive.

Indigenous youth have been especially affected by highly limited state-funded scholarship opportunities and the de facto abolition of the Soviet system of targeted enrollment of Indigenous students. To address this issue, new initiatives for new enrollment programs have been presented by the Russian Association of Indigenous Peoples of the North (RAIPON) [65,66], which may have a positive effect on educational and career opportunities for Indigenous youth in the near future. Also, in 2020, the YaNAO government 
initiated a regional limited support program for Indigenous students to compensate for their education costs [67].

Typical of many Arctic resource-based economies, gender segregation in labor markets [68-70] sharply appears in both Arctic regions and primarily affects women by narrowing their chances for economic empowerment to traditionally female occupations in the social and NGO sphere, education, medicine, and public (municipal) administration. Nevertheless, there are strong signs of young women's growing interest and involvement in entrepreneurship and social entrepreneurship, particularly. Since 2018, both regional governments subsidize small business initiatives, organize educational training programs, and provide opportunities for mothers with small children to get back to work (for instance, the Yamal educational project "Mom Is an Entrepreneur" [71]). YaNAO also has one of the highest ratings of governmental support out of all Russian regions for socially oriented NGOs [72] to promote and encourage predominantly female social entrepreneurship. Although the YaNAO and NAO programs are not aimed at overcoming traditional gender-based labor division, they firmly intend to create more opportunities for women in the local labor markets.

\subsection{Educational Opportunities and Career Prospects through the Eyes of the Local Youth}

The results of the youth survey revealed that to be competitive in the Arctic labor market, young people approaching high school or vocational school graduation who seek higher education opportunities and higher social status have to leave.

In Naryan-Mar, $9 \%$ of male and $8 \%$ of female high school students stated their intention to live in their home region (Table 1), while in Salekhard and Novy Urengoy, it is only 4 (!) $\%$ for both genders, respectively (Table 2 ).

Table 1. Settlement preferences among high school students (14-17 y.o.) in Naryan-Mar (\%, participating respondents).

\begin{tabular}{cccccccc}
\hline \multirow{2}{*}{ Planning to Live in } & \multicolumn{2}{c}{ No } & \multicolumn{2}{c}{ Not Sure } & \multicolumn{2}{c}{ Yes, Most Probably } \\
\cline { 2 - 8 } & Male & Female & Male & Female & Male & Female \\
\hline NAO & 72 & 64 & 18 & 28 & 9 & 8 \\
\hline Another region in Russia & 9 & 8 & 36.5 & 20 & 54.5 & 72 \\
\hline Another country & 54.5 & 76 & 27.5 & 4 & 18 & 20 \\
\hline
\end{tabular}

Source: Author's survey, conducted with Dr. Andrey Gretsov (high school students from Naryan-Mar).

Table 2. Settlement preferences among high school students (14-17 y.o.) in YaNAO cities of Salekhard and Novy Urengoy (\%, participating respondents).

\begin{tabular}{cccccccc}
\hline \multirow{2}{*}{ Planning to Live in } & \multicolumn{2}{c}{ No } & \multicolumn{2}{c}{ Not Sure } & \multicolumn{2}{c}{ Yes, Most Probably } \\
\cline { 2 - 8 } & Male & Female & Male & Female & Male & Female \\
\hline YaNAO & 77 & 64 & 19 & 32 & 4 & 4 \\
\hline Another region in Russia & 8 & 5 & 11 & 19 & 81 & 76 \\
\hline Another country & 54 & 45 & 31 & 40 & 15 & 15 \\
\hline
\end{tabular}

Source: Author's survey, conducted with Dr. Andrey Gretsov (high school students from Salekhard and Novy Urengoy).

In the boarding school in Naryan-Mar, among predominantly Indigenous students, $17 \%$ of male and $26 \%$ of female students see their future in NAO (Table 3). On the one hand, these numbers reflect that Indigenous people in the Arctic keep strong bonds with their lands. On the other hand, they may also reflect that students' parents who live in rural areas and are involved in subsistence economy might have less financial aid to pay tuition and living costs to send their children to obtain better degrees [73]. 
Table 3. Settlement preferences among predominantly Indigenous high school students (14-17 y.o.) in Naryan-Mar (\%, participating respondents).

\begin{tabular}{cccccccc}
\hline \multirow{2}{*}{ Planning to Live/Study in } & \multicolumn{2}{c}{ No } & \multicolumn{2}{c}{ Not Sure } & \multicolumn{2}{c}{ Yes, Most Probably } \\
\cline { 2 - 8 } & Male & Female & Male & Female & Male & Female \\
\hline NAO & 57 & 36 & 26 & 38 & 17 & 26 \\
\hline Another region in Russia & 24 & 24 & 10 & 38 & 66 & 38 \\
\hline Another country & 76 & 83 & 14 & 10 & 10 & 7 \\
\hline
\end{tabular}

Source: Author's survey, conducted with Dr. Andrey Gretsov (high school students of the Pyrerka Boarding school in Naryan-Mar).

Nearly one third of vocational students from our focus groups expressed their intent to stay in their regions; others, to a greater or lesser degree, are considering relocation as a part of their life strategy (Tables 4 and 5).

Table 4. Settlement preferences among vocational college students (17-21 y.o.) in Naryan-Mar (\%, participating respondents).

\begin{tabular}{cccccccc}
\hline \multirow{2}{*}{ Planning to Live in } & \multicolumn{2}{c}{ No } & \multicolumn{2}{c}{ Not Sure } & \multicolumn{2}{c}{ Yes, Most Probably } \\
\cline { 2 - 7 } & Male & Female & Male & Female & Male & Female \\
\hline NAO & 23.5 & 26 & 43 & 42 & 33.5 & 32 \\
\hline Another region in Russia & 33 & 48 & 40 & 20 & 27 & 32 \\
\hline Another country & 80 & 72 & 20 & 24 & 0 & 4 \\
\hline
\end{tabular}

Source: Author's survey, conducted with Dr. Andrey Gretsov (vocational students in the colleges of Naryan-Mar)

Table 5. Settlement preferences among vocational college students (17-21 y.o.) in YaNAO cities of Salekhard and Novy Urengoy (\%, participating respondents).

\begin{tabular}{cccccccc}
\hline \multirow{2}{*}{ Planning to Live in } & \multicolumn{2}{c}{ No } & \multicolumn{2}{c}{ Not Sure } & \multicolumn{2}{c}{ Yes, Most Probably } \\
\cline { 2 - 7 } & Male & Female & Male & Female & Male & Female \\
\hline YaNAO & 18.5 & 50 & 46.5 & 16.5 & 35 & 33.5 \\
\hline Another region in Russia & 33 & 44 & 37 & 17 & 30 & 39 \\
\hline Another country & 54 & 78 & 33 & 11 & 13 & 11 \\
\hline
\end{tabular}

Source: Author's informal survey, conducted with Dr. Andrey Gretsov (vocational students in the colleges of Salekhard).

Among the vocational students who indicated a willingness to relocate to other cities/regions/countries, $86 \%$ planned to obtain higher degrees and get better skills to compete in the job market.

\subsection{Employment Opportunities through the Eyes of the Local Youth}

Despite the relative economic prosperity of these two Arctic regions and low unemployment rates among the young (ISO Indicator 5.4: 3.7\% for Salekhard and Novy Urengoy, and 4.7\% for Naryan-Mar [74] (Appendix A, Table A1)), local Arctic youth—both Indigenous and non-Indigenous-anticipate difficulties in finding suitable jobs and are mostly pessimistic about their prospects in hometowns.

For instance, college students found themselves in a challenging position: In YaNAO, $50 \%$ of females and $30 \%$ of males expressed strong concerns about their employment and job possibilities, pointing out a "lack of jobs" - mainly due to competition in the local labor market; in NAO, those percentages were $60 \%$ and $50 \%$, respectively.

High school students also indicated significant obstacles to getting a job in the local labor market. In NAO, $36 \%$ of female and $18 \%$ of male students pointed out "lack of vacant jobs/lack of jobs in the certain specialty"; $27 \%$ of male students also mentioned "low 
educational level", and 18\% "high competition" and "low paid jobs". In boarding school, students (predominantly Indigenous) indicated even deeper concerns: $48 \%$ of females and $24 \%$ of males pointed out "lack of vacant jobs/lack of jobs in the certain specialty"; $21 \%$ of females also indicated "low educational level", and 14\% of males- "high competition".

In YaNAO, $26 \%$ of females and $27 \%$ of males indicated "low educational level"; $24 \%$ of female and $15 \%$ of male students pointed out "lack of vacant jobs/lack of jobs in the certain specialty"; $26 \%$ of female and $15 \%$ of male students pointed out "lack of professional experience". Also, $27 \%$ of males indicated "high competition".

In all groups, students of both genders often mentioned, among other factors, "lack of professional experience" (often required by employers), "low paid jobs", "family issues", including "family's disapproval of professional choice", "laziness", and "low confidence", "lack of connections", "financial issues" (no possibilities to relocate or to start a small business), "limited job vacancies available", "a highly narrow, single-industry economy and the [economic - author's] underdevelopment in the region", etc.

Continuing professional development and career building in the Arctic is also viewed as problematic for respondents. Among the main reasons, they mentioned "narrow range of professions", "underdevelopment of the region", and "not enough opportunities to carry out certain activities" (female students, NAO); "few centers with diverse areas of professional activity", "it is hard to get the initial capital for professional growth and get a job with a good salary and [with the prospect - author's] of growth on the career ladder; it is challenging, you need to be a first-class professional" (male students, YaNAO). At the same time, as was illustrated by the survey participant, good education combined with professional competence is the key to success in their hometowns: "With a good education and professional skills, competition is reduced at times" (male college student, NAO).

The study also revealed gender differences in students' career preferences and that gender-related imposed choices of professions are more prevalent among females. Female students tend to think big and outside the box. Overall, they may have great potential for professional growth and future empowerment. However, even though they are inspired to be geologists, policewomen, ecologists, customs officers, chemists, movie producers, pharmacists, architects, and prosecutors, many emphasized the gap between personal aspirations and realities. They admitted that they were more likely to become (pre)schoolteachers, nurses, etc. For instance, in Naryan-Mar, predominantly Indigenous female students (14-17 y.o.), who came from remote Indigenous communities or originated from families pursuing traditional, including nomadic, lifestyles in remote rural areas of the NAO, demonstrate significant shifts in career strategizing while admitting the insurmountable obstacles to achieving their goals:

"I really want to work in law enforcement agencies, in the police. However, I'm not sure whether I can enter and learn this profession with my academic performance. In this case, I am thinking of applying to be a preschool teacher" (female student, NAO); "I would love to become a choreographer, but I am thinking about the profession of a physical education teacher in a school" (female student, NAO).

Among other barriers for youth's employment in their Arctic regions that cannot be seen in official statistics and reports, the respondents pointed out various forms of nepotism and cronyism in the labor market, with elements of the closed culture of corporatocracy:

"If you do not have good connections and money, then you will not have any professional growth" (female student, NAO); "If you do not have friends, it is hard to get a job" (male student, YaNAO); "You can get a job (good, well paid) ONLY through CONNECTIONS" (male vocational student, YaNAO); "A large number of private entrepreneurs hire relatives" (male vocational student, YaNAO).

Out of many advantages of working in the North, the young respondents primarily acknowledged the government economic and social support system built in the Soviet era to stimulate Arctic regional development [75-78]. For instance, among the advantages of 
working in YaNAO, 50\% of female and 53\% of male college students mentioned higher salaries and Northern allowances, and $17 \%$ of females and $20 \%$ of males mentioned long vacations. Also, $27 \%$ of male students highlighted early retirement with additional allowances vs. just $6 \%$ of females, respectively ("Working in the YaNAO, your length of service is calculated one year for two, or, in some cases, for three years. In other words, you can earn a pension faster here and receive a Northern allowance on top of your pension" (female college student, YaNAO)). In NAO, 36\% of female and 53\% of male college students mentioned higher salaries and Northern allowances.

On the one hand, high school respondents believed that the underdeveloped service sphere and undiversified Arctic economy potentially open vast opportunities for starting their own businesses (17\% of female students in YaNAO and $20 \%$ of female students in NAO vs. $0 \%$ of males, respectively): "There are advantages for the development of small businesses, since there are not enough here" (female student, YaNAO); “ . . to open a production line of goods that are not available in the region" (female student, NAO). On the other hand, high school students, especially females, less reliant on the paternalistic model of governance, see very few or no advantages and prospects in the Arctic regions (22\% of females in YaNAO and $28 \%$ in NAO).

In YaNAO, among the five top-rated future prospective labor sectors in their regions, students, especially females, identified those related to the government and governmentfunded sectors (schools, hospitals) or big businesses with a high level of government involvement (oil and gas industries). Female students also view jobs in the traditional female domain as the most prospective- $44 \%$ in medicine and $33 \%$ in education-while male students chose the male-dominated IT sphere (see Figure 4).

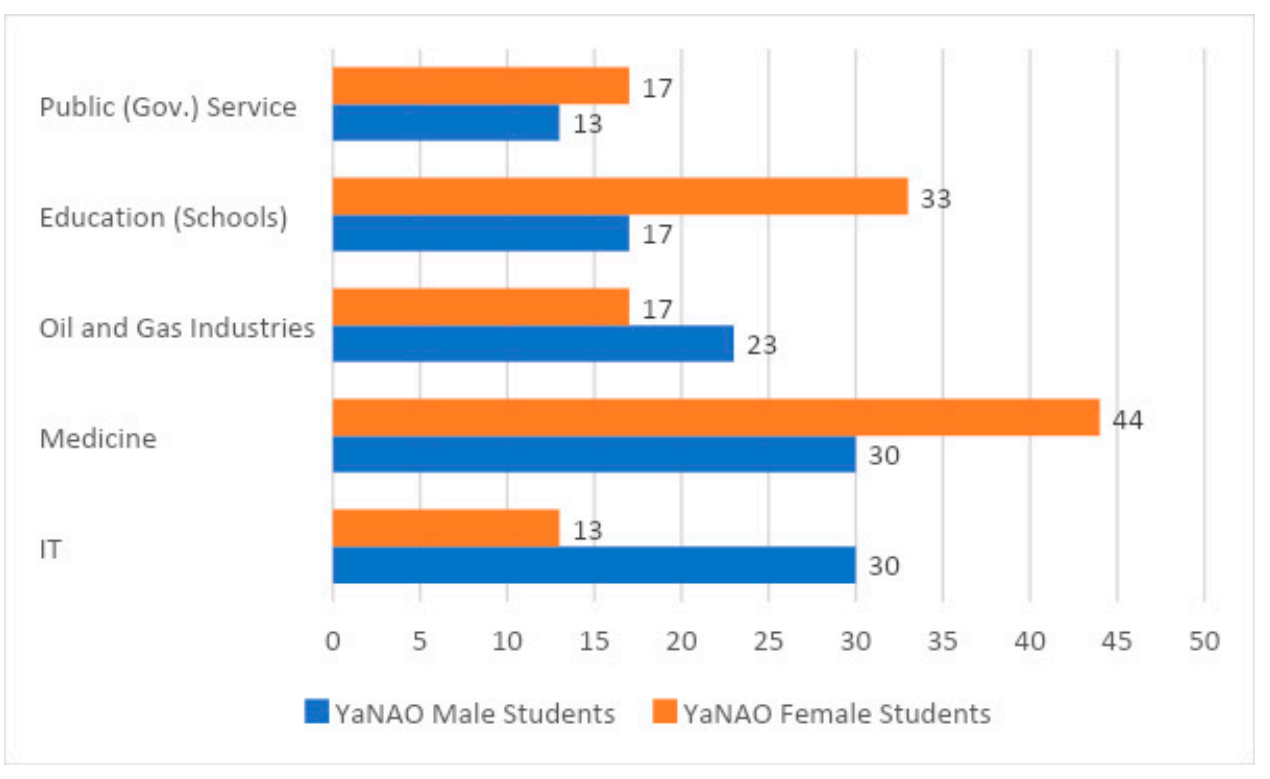

Figure 4. YaNAO vocational students' choices of future prospective labor sectors in their regions. Top 5 identified (\%).

In NAO, with minor exceptions similar to Yamal, both male and female students are also in a path dependency situation. While females consider education (44\%) and medicine ( $36 \%$ ) among their top spheres, males view the oil and gas industries and reindeer husbandry as the core of Nenets's traditional economy, as well as transportation and construction as the most attractive and promising professions in NAO (Figure 5). 


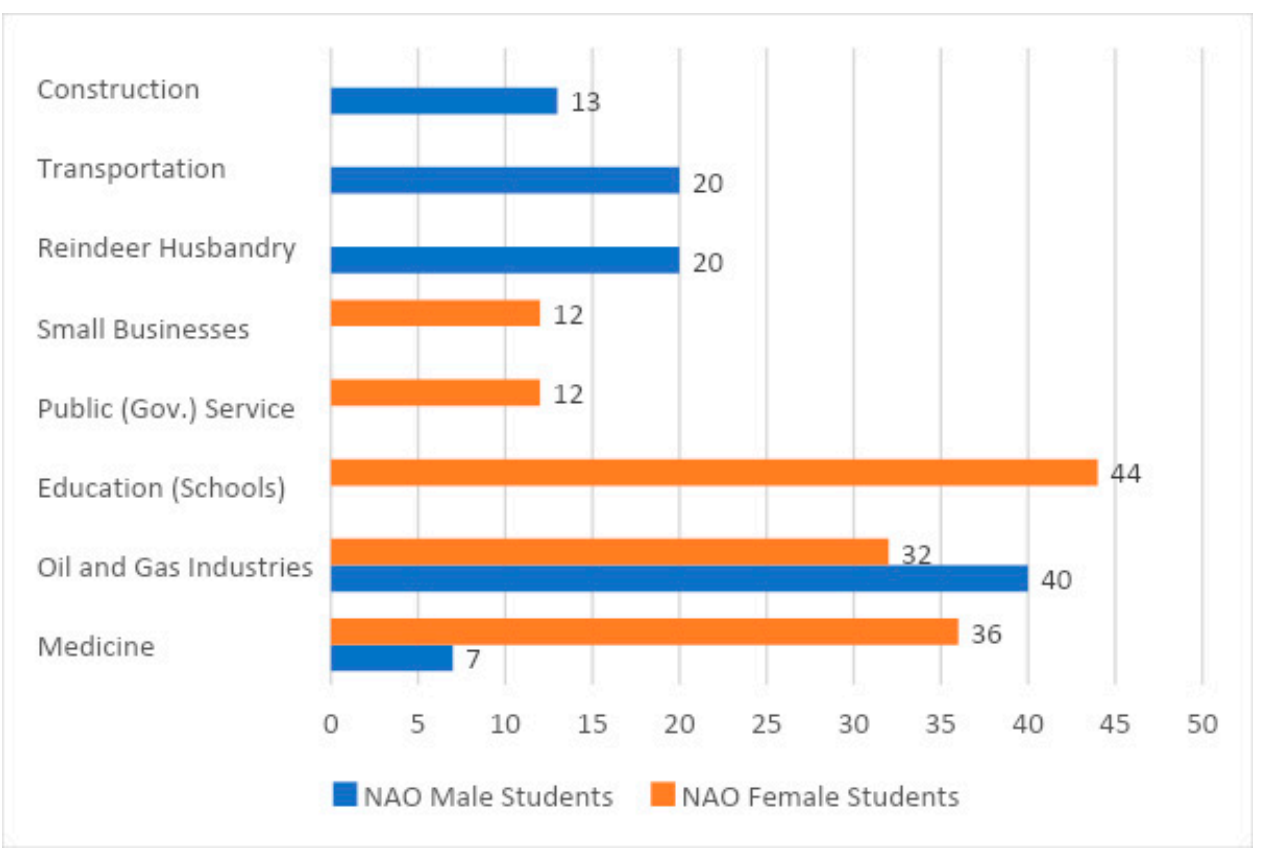

Figure 5. NAO vocational students' choices of future prospective labor sectors in their regions. Top 5 identified (\%).

\subsection{Opportunities for Cultural Activities, Sports, and Entertainment: General Overview of Cultural Infrastructure}

Regarding cultural infrastructure, "the number of cultural institutions, such as theaters, movie houses, and libraries, is only a starting point for understanding the cultural vitality of the city" [13] (p. 284) (ISO indicator 17.1, "Number of cultural institutions and facilities per 100,000 population"). The cultural indicator values (28 for Naryan-Mar, 22 for Salekhard, and 17.2 for Novy Urengoy (Appendix A, Table A1)) do not explain the real spectrum of opportunities for diverse young urbanites in the cultural sphere and therefore require a broader context.

In NAO and YaNAO, revenues coming into the regional budgets from extraction businesses allow local authorities to invest in cultural infrastructure, yet the policy implications differ in each of the three cities. Rooted in the Soviet tradition of formal cultural recognition [79], cultural policy priorities are largely determined by cities' ethnic composition and share of Indigenous population (Table 6).

Given the increasing trend of Indigenous urbanization, governments in both regional capitals-Salekhard and Naryan-Mar-acknowledge Indigenous heritage and emphasize symbolic recognition policies by "Indigenizing the urban landscape", supporting and promoting refined forms of Indigenous cultures [79]. While meaningful to Indigenous youth, these cultural initiatives do not equally benefit all Arctic youth groups.

The private sector in the sphere of culture is mostly underdeveloped, especially in Naryan-Mar and Salekhard, because of the low number of their population that does not generate great consumer demand. For instance, in YaNAO, the share of private businesses in the total number of organizations providing cultural services is $25 \%$ (for comparison, in Russia it is 53\%, 2018) [6] (p. 56). To a lesser or greater extent, all three cities are experiencing a deficit of services of high importance for urban youth social life-cinemas, commercial concert halls hosting diverse and popular artists, diverse meet-up places for amateur interest groups, non-government youth creativity centers, as well as professional theatres s [80] (Figure 6). 
Table 6. Ethnic composition of the cities: largest ethnic groups (\%).

\begin{tabular}{cccc}
\hline Major Ethnic Groups & Naryan-Mar & Salekhard & Novy Urengoy \\
\hline Russians & Non-Indigenous & & \\
\hline Ukrainians & 2.35 & 61.27 & 64.14 \\
\hline Tatars & 0.56 & 5.80 & 10.76 \\
\hline Belarusians & 0.70 & 8.50 & 4.99 \\
\hline Azeris & 0.63 & 0.74 & 1.95 \\
\hline Bashkirs & - & - & 1.69 \\
\hline Nogais & - & 0.58 & 2.61 \\
\hline Kumyks & - & - & 2.06 \\
\hline Chechens & - & - & 1.12 \\
\hline Kyrgyz & - & - & - \\
\hline Nenets & Indigenous & & - \\
\hline Komi/Komi-Zyrayane & 7.30 & 2.83 & - \\
\hline Khanty & - & 2.56 & - \\
\hline
\end{tabular}

Source: The Russian Census of 2010 (latest available data).

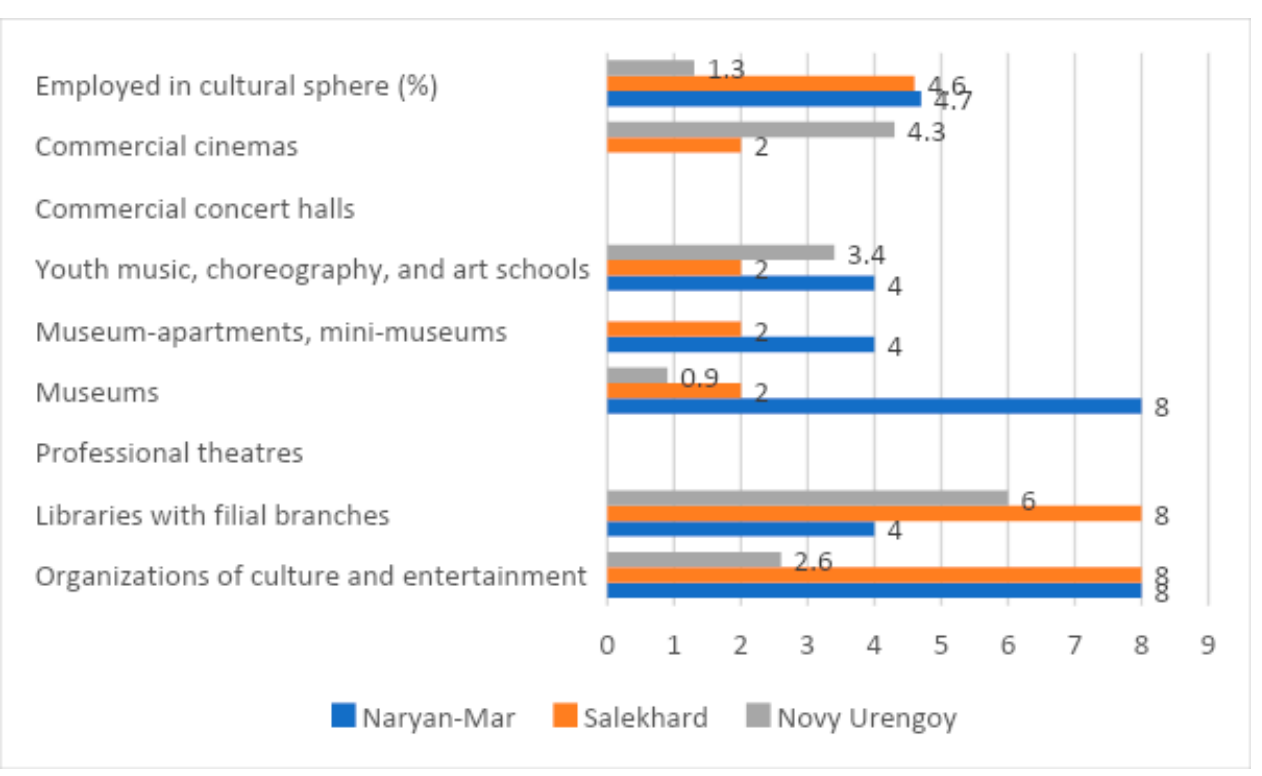

Figure 6. Number of cultural institutions (facilities) per 100,000 people, and employment in the cultural sphere (as a percentage of total employed). Sources: Author's calculations based on Municipal Statistics, Federal State Statistics Service of the Russian Federation (Rosstat), 2019 (latest available data); Regiony Rossii. Sotsial'no-ekonomicheskiye pokazateli - 2019. Rosstat:Moscow, 2019; 2gis.ru.

\subsubsection{Cultural Facilities in Naryan-Mar: Diversity in the Monotony}

Despite a high value for the 17.1 ISO indicator, not all cities' cultural facilities meet the expectations of different local youth groups. Naryan-Mar has a rather ethnically homogenous society with a relatively significant share of Indigenous population and limited cultural diversity policies: The cultural institutions are mostly folklore-oriented and work as fabrics for refining primarily Arctic Indigenous art and culture. For instance, under the umbrella of the budget-funded Culture Center "Arktika" and Ethnocultural Center, out of thirteen dance, choir, and theatrical studios with young people, only four 
are relevant to youth modern mainstream culture. The rest are folk-specific and, although culturally diverse, limited to Northern (including Russian) cultures only. Growing ethnic groups (both new and well-established but small-numbered) are not very well represented in the cultural sphere. Despite officially registered Dagestani, Tatar-Bashkir, and Chuvash associations [81], and Azeri people's visible presence, they are not perceived as an integral "permanent" part of the cultural and social fabric and thus not equally displayed in the public cultural domain.

Such a practice of selective cultural inclusion might also be influenced by the general public's views in this region on diversity policies: A public survey conducted in 2019 revealed that only $53 \%$ of respondents believed that all residents of ethnically defined autonomies, such as $\mathrm{NAO}$, have equal rights regardless of their ethnic background; $37.5 \%$ expressed a strong belief that Indigenous Peoples are entitled to have more rights in their ancestral homeland than other ethnicities; 9\% did not have an opinion about this matter [81].

Functionalities of other city cultural institutions are somewhat narrow and oldfashioned and play a minimal role in young city dwellers' everyday lives. The Central Library of NAO in Naryan-Mar offers special events and programs mainly oriented to children and older adults. Nenets Regional Museum of Local Lore has rich permanent collections and professional tours led by historians and Indigenous researchers. However, they are rather tourist-oriented and not a constant point of attraction for young locals.

\subsubsection{Cultural Facilities in YaNAO: Move towards a Greater Diversity}

In YaNAO, both focal cities with their more significant mobility patterns present "an ongoing progressive move from a Eurocentric culture toward greater hybridization" [82] (p. 3) and more versatile cultural policies that are acclimating to better meet youth's expectations. The Department of Culture of the YaNAO focuses on preserving and developing cultural heritage and the inclusion of trendy, modern styles.

Novy Urengoy, as a young single-industry city founded in 1975 without much of a historical legacy beyond gas exploration, does not have a variety of museums except the Gazprom Museum and Art Museum, the only one in Yamal. Despite that, the city's support for popular youth cultures and diverse activities makes it more attractive for the young generation. It also contributes to and defines the Arctic shifting identity with emerging forms of Arctic ethnic and cultural diversity [83] and provides more opportunities for young newcomers to integrate into the Arctic mosaic social fabric.

In Salekhard, government-supported ensembles and studios that welcome young people reflect growing cultural diversity. Among them are the folklore ensembles of the peoples of the North Caucasus "Siyanie gor", Tatars and Bashkirs "Duslyk", and Mari people "Mari Kundem". Overall, out of eleven government-funded cultural projects, only three are ethnically neutral, and out of eight ethnically oriented projects, five promote the Indigenous cultures of the North.

The Department of Culture of YaNAO made a successful attempt to revitalize oldfashioned "monofunctional" cultural institutions to make them constant points of attraction for diverse cultural, intellectual, and social activities (for instance, the project "New Library of Yamal" [84]; a good example here is the remodeling and reformatting of the Yamal National Library in 2017). Importantly, it has also supported inclusivity in the cultural sphere by establishing a studio of creativity for people with disabilities.

\subsubsection{Cultural Economy for Indigenous Youth}

In Salekhard and Naryan-Mar, the Soviet cultural recognition policies' legacies are still vital and set the agenda in the cultural domain. As demonstrated in some Indigenous studies, the developed cultural economy is of crucial importance to many Indigenous urbanites: Although Indigenous communities' sustainability was initially based on "an appreciation of intimate relationships between humans and the local environment [...], in the urban setting, these relationships have been mediated by infrastructural develop- 
ment" [80], particularly cultural infrastructure. The cultural sphere is of crucial importance as Indigenous urbanites often play the "social roles of professionals in organizing ethnic processes in the urban space" [85]. The indicator "Employment in the cultural sphere (as a percentage of total employed)" (Appendix A, Table A1) demonstrates high rates of government-funded employment in the cultural sphere for Naryan-Mar and Salekhard ( $4.6 \%$ and $4.7 \%$ respectively of total employed vs. $1.3 \%$ in Novy Urengoy). Although additional research is needed, it is possible that these employment opportunities also serve to strengthen the social and cultural capital of local Indigenous Peoples and may contribute to Arctic social substantiality.

\subsection{Sports Infrastructure}

All three Arctic cities have a high number of sporting facilities (Figure 7 presents Indicator 17.1 (Appendix A, Table A1)). Generously (co-)sponsored by the oil and gas corporations, they are an example of successful promoting and popularizing of sport among youth.

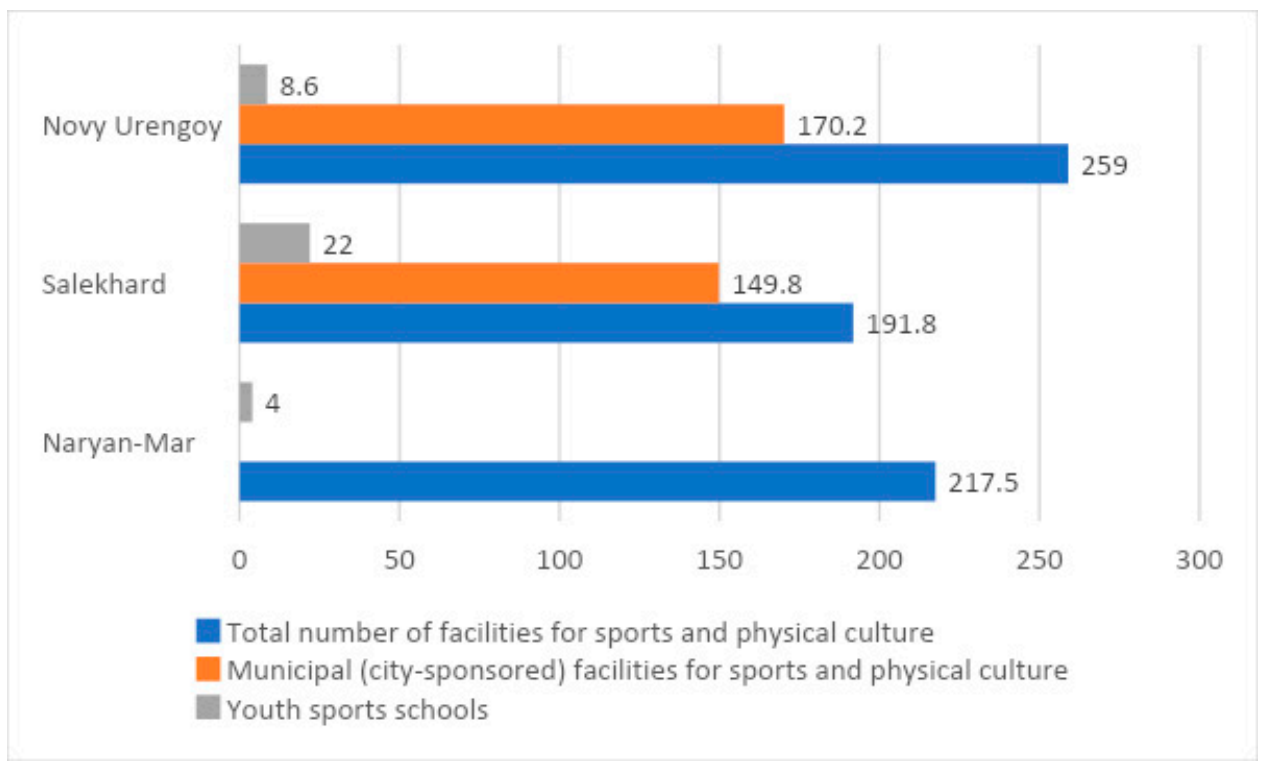

Figure 7. Number of sporting facilities per 100,000 people. Sources: Municipal Statistics, Federal State Statistics Service of the Russian Federation (Rosstat), 2019 (latest available data).

Similar to the cultural sphere, which acknowledges Indigenous heritage, popular sports in Salekhard and Naryan-Mar are complemented by sports sections facilitating the development of Indigenous traditional sports and supporting professional competitions. In the case of sports, a higher value of the sports variable indicates an improvement in the quality of life of Arctic youth.

\subsection{Arctic Youth's Leisure Time}

Youth involvement in cultural, sporting, and other social activities and the degree of social integration and levels of social contributions to their Arctic communities among youth can be measured through the component of leisure time and its structure (based on [86]).

Similar to the general population of Russian youth [87], the structure of Arctic youth's leisure time is not very diverse. It varies depending on gender, specific age group, status (high school students or vocational students), ethnicity (Indigenous/non-Indigenous), and time of year. Leisure time structure also varies based on the availability and affordability of cultural, sporting, and entertainment facilities in hometowns.

In wintertime, both cohorts of the young generation-high school and vocational students-mostly prefer to stay at home but also spend some of their leisure time outside, 
in the fresh air (see Figures 8 and 9). While spending time indoors (at home or in youthoriented centers), female students at school age, in particular, are increasing their cultural capital. They are inclined to do something creative (e.g., writing, painting, playing music, drawing, cooking, vocal singing, caring for botanic flowers, photo sessions, stucco figures modeling, etc.) and read books.
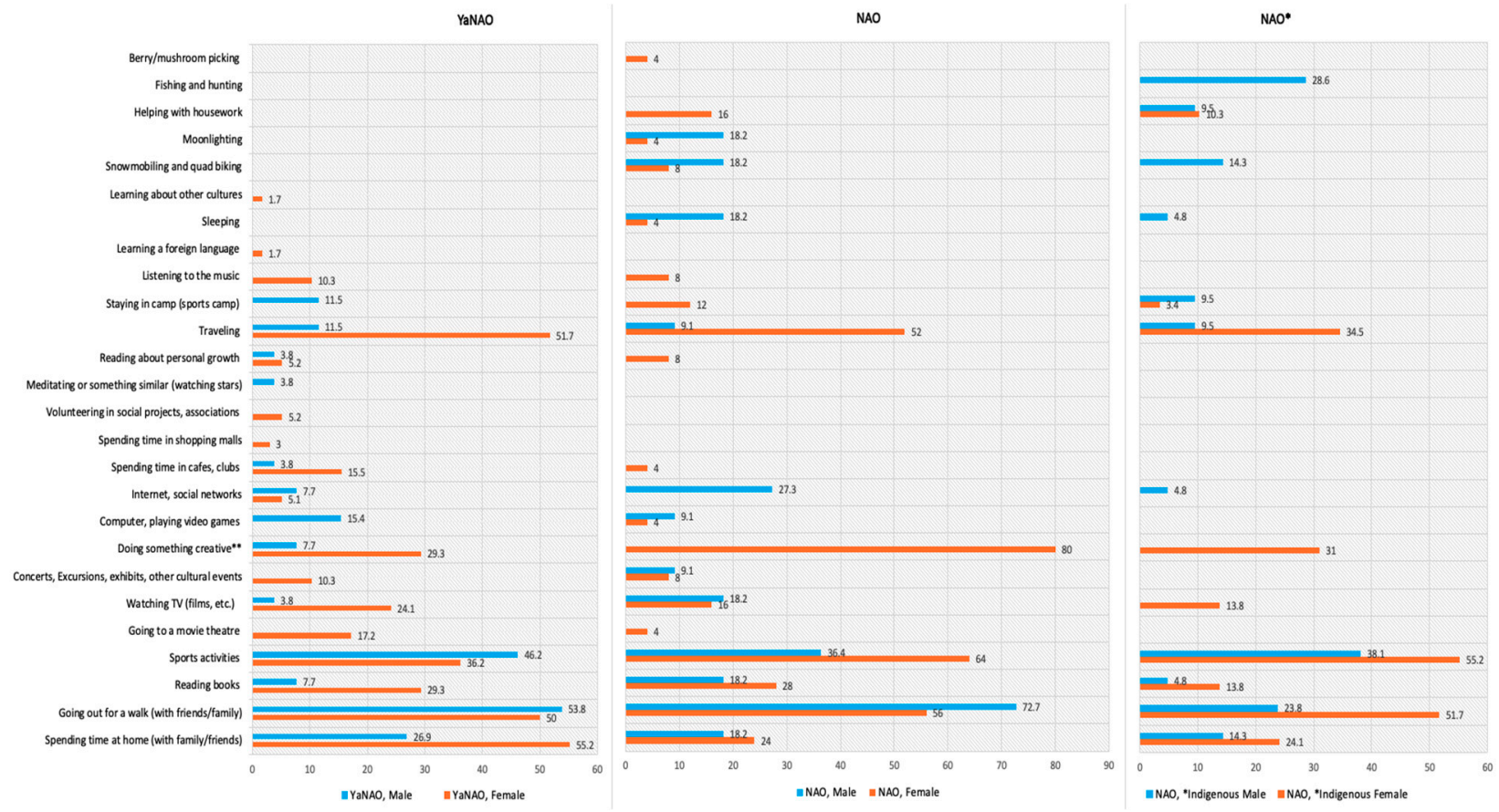

Figure 8. High school students from NAO and YaNAO, open question: "What activities are you engaged in during your leisure time? Where do you spend your leisure time?" (\% of all collected responses in each group). * Students at the boarding school, predominantly Indigenous students. ** Includes activities such as writing, painting, playing music, drawing, cooking, vocal singing, caring for botanic flowers, photography sessions, modeling stucco figures, etc., and time spent in youth centers for creativity.

Based on survey results, indoor and outdoor sports activities play a vital role in the respondents' lives, and youth appreciate existing facilities in all three focal cities. With the exception of YaNAO male school students, sports are more prevalent among females. Both female and male respondents have a comprehensive range of sporting activities. Females are engaged in skiing, ice skating, cycling, rhythmic gymnastics, dancing, boxing, swimming, and volleyball, while male respondents prefer snowboarding, football, swimming, martial arts, volleyball, basketball, boxing, skiing, and biking. Almost one third of high school and vocational male students in NAO (28.5\% and 33.3\% respectively) and vocational male students in YaNAO are engaged in hunting and fishing, and Indigenous male students also practice reindeer herding.

In contrast to vibrant sports facilities, cultural infrastructure and public entertainment facilities are not satisfactory for local youth. Based on their responses, the share of school students going to cafes (in YaNAO, 15.5\% of females and 3.8\% of males; in NAO, $4 \%$ of females), movies (in YaNAO, 17\% of females; in NAO, $4 \%$ of females), concerts, exhibits, and other cultural events (in YaNAO, 10.3\% of females; in NAO, $8 \%$ of females and $9.1 \%$ of males) is relatively low, while vocational students and Indigenous school students did not mention engagement in any cultural and social activities. 

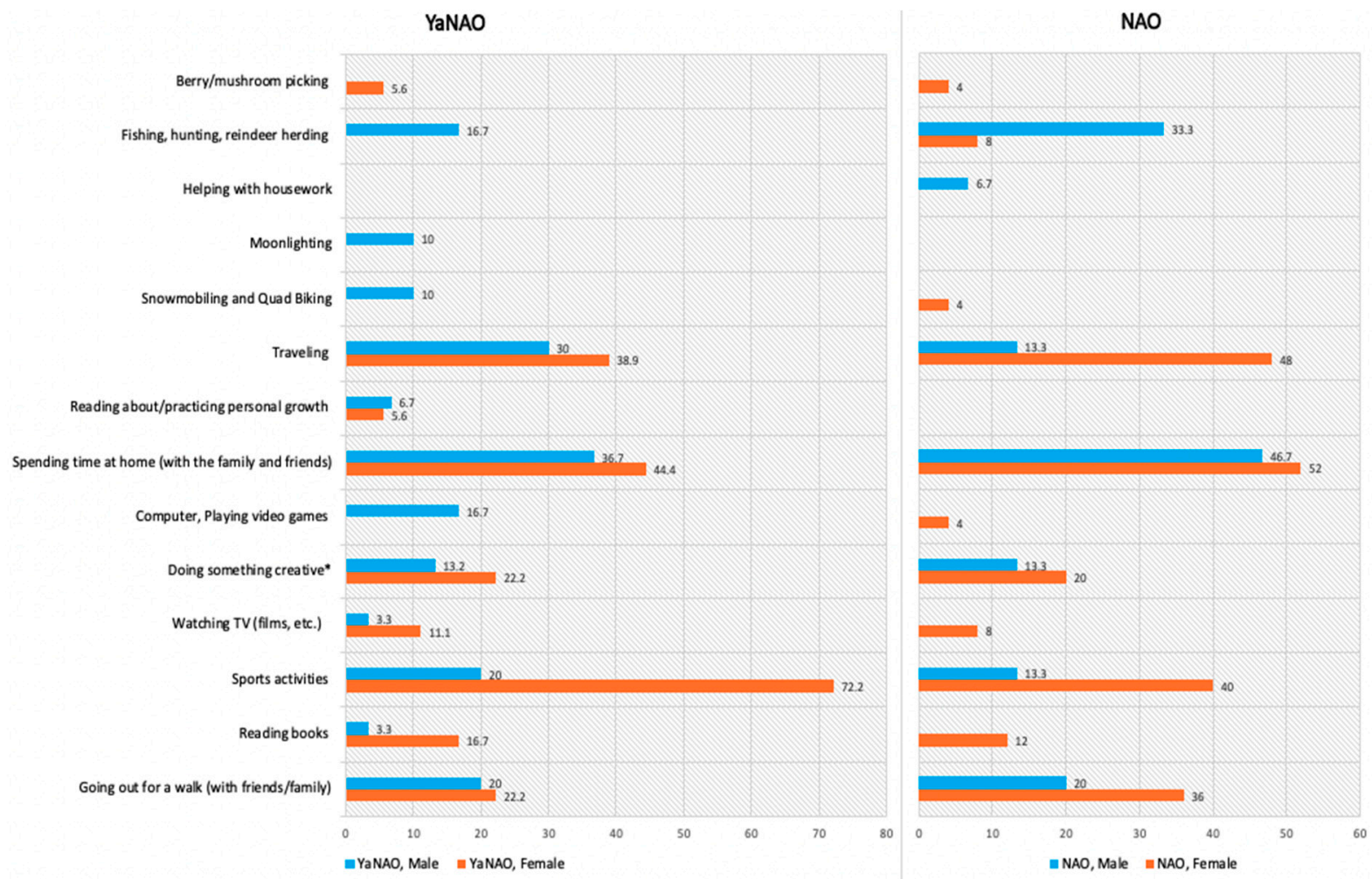

Figure 9. Vocational students from YaNAO and NAO, open question: "What activities are you engaged in during your leisure time? Where do you spend your leisure time?" (\% of all collected responses in each group). * Includes activities such as writing, painting, playing music, drawing, cooking, vocal singing, caring for botanic flowers, photography sessions, modeling stucco figures, etc., and time spent in youth centers for creativity.

Two of the most common comments among youth are that "there are very few places to go" (female student, NAO) and "these places are not cheap" (female student, YaNAO).

Local recreational activities such as tourism are still minimal in these Arctic regions due to transport isolation and undeveloped tourism clusters. Based on students' responses, when it comes to traveling, they go to the "South" of Russia for a vacation to stay with their relatives, youth camps, the warm sea, or abroad, or they visit their relatives in the Northern villages in the Arctic tundra. Those staying in their hometowns mentioned active outdoor recreational activities with friends and spending time in the suburbs.

"In summer, I travel with my parents to the sea; in winter, because of the severe cold, I stay at home and read" (female student, YaNAO); "I usually spend summer in the village and do nothing interesting, because there is nothing to do there" (female student, boarding school, NAO); "I stay at home in winter, and go out in summer" (male vocational student, YaNAO).

As the surveys show, youth spend plenty of time socializing with immediate relatives and friends. Following a general trend for Russia [87] (p. 113), the respondents did not indicate that they allocate time and effort to public activities or community service: Out of all collected questionnaires, only two respondents mentioned their social contribution through involvement in volunteering activities. The harsh Arctic climatic conditions could be one of the reasons for such a low level of participation as they may naturally limit the youth's engagement in these types of work. Long Polar winters and extreme cold also push young urbanites to stay at home, while in the summertime, Northerners tend to leave their cities. 


\section{Discussion}

The study results show that youth migration decisions are complex and multifaceted. The present analysis is based on the dualist pull and push factors of migration. Although decisions to stay or leave are influenced by a broad range of social, professional, and economic factors and often shaped within a family context, our study identified that like in many other remote regions of the Circumpolar North, the lack of good-quality (higher) education opportunities is a key push factor and a driver of local youth outmigration $[29-36,88]$.

In the sphere of education, the survey respondents from high schools (predominantly female students) in all three cities pointed out an acute problem common to most Arctic communities-the shortage or limited range of available educational services [88]. In particular, they identified the lack of higher education institutions in their regions as a substantive personal problem. Without higher education and relevant professional experience, local young people have few chances to build their careers in the extraction industries and other businesses or legislative and executive branches of government that would allow them to raise their social status, improve their material well-being, and fulfill their dreams.

The students' professional considerations are complex. Based on the school students' choices of specific professions, it is possible to presume their future educational and migration strategies. With a slight exception of Indigenous male students, all focal groups in Naryan-Mar, Salekhard, and Novy Urengoy expressed a strong interest in professions requiring higher education. Moreover, many of those preferred professions (e.g., orientalist, diplomat, movie producer, forensic expert, ecologist, architect, chemist, linguist, scientist-physicist/astrophysicist, etc.) are unavailable or have limited availability in these remote and economically less dynamic and developed Arctic regions. Indigenous male students were generally focused on occupations that do not require much modern (Western) professional training. Although more research is needed, it is possible to assume that they probably would be more interested in "Indigenized" education programs that have been established in other Arctic states with an emphasis on traditional knowledge and practices [88], should these programs become available in Russia. The surveys also indicate that local young people, especially vocational students, feel tremendous pressure to succeed in the Arctic labor market. Competition in the local labor markets can be defined as another strong push factor. Local youth without higher education face direct competition with lowand semi-skilled newcomers while not being able to apply for high-skill jobs that require higher education. This situation is also common for most remote Arctic regions where companies are reluctant to hire locals [55-59]. Among other push factors, the respondents of youth surveys and education/employment professionals pointed out corruption (mainly in the form of nepotism and cronyism) in the public sector of employment and broader labor market, with the dominance of the closed culture of corporatocracy.

Although locals do not have access to many high-wage jobs in their regions and are de facto limited with a minimal list of available occupations, the Northern labor market, with its social benefits system, seems attractive for many local young people. Established by law, so-called "Northern allowances" compensating workers for the higher cost of living and offering long paid vacation with travel compensations, early retirement, and a shorter working week (particularly for women) [75-78] are perceived as the key pull factor to retain youth. Also, the dominant non-diversified and single-industry economy, which is usually defined as a push factor, can be viewed as a pull factor. For instance, female students believe in other advantages of working in the North, besides benefits and social protection measures. They see many vacant niches (e.g., service industries and small businesses) and envision opportunities to develop small businesses to diversify the Arctic economy.

In the sphere of social integration, urban Arctic youth demonstrate low engagement in community services and the voluntary sector. Despite such "social atomization" (revealed in fragmentation of social networks and internally divided communities) of the young in the public domain, they are not experiencing an "individual atomization". Just the 
opposite, based on questionnaires, young people are attempting a high level of individual integration by maintaining strong social networks within their smaller inner circles of close friends and relatives or people who share their interests. The consequences for communities include a decreasing level of mutual trust outside residents' inner circle of friends and relatives, as well as a reduced level of public participation and sense of commitment toward improving their places [89], solidarity, and joint efforts to invest in the "common good" to fill a social vacuum between different "inner circles". As the value of community as a whole and intergenerational equity and trust are decreasing, nepotism is growing, along with the sharp divides between different groups of settlers (old-timers and newcomers, and FIFO workers) and between settlers and Indigenous communities. The underlying causes of Arctic youth's "social atomization" are in many ways rooted in their future (forced) life choices to relocate, thus contributing to a reduced feeling of attachment to their communities [90]. A critical imperative that affects Arctic youth's attachment to place is a well-rooted tradition of upward migration to the North inherent in many settler families and limited to one to three generations [50]. Young people are often encouraged by their parents to leave their hometowns for a "better life in the mainland": "We've been through a lot here, built our careers and everything, let our children to have a better life in good climate and better career opportunities" (Public official, Salekhard); "We came here [Naryan-Mar - author's] for career opportunities, [big-author's] "Northern money" and privileges [with intention - author's] to work for 10-15 years and then to go back to mainland. Actually, this is a good place to raise kids. The city is safe and compact with many opportunities for sports and creativity classes. But we are not planning to stay here after our public service is done" (Public official, Naryan-Mar); "Of course, I want my daughter to go to the University and to find a job somewhere else. What has she seen here? Look, there are even no real trees here, just permafrost all around and cold" (Public official, Novy Urengoy). This also often prevents young people from establishing stronger ties with their hometowns and reduces their willingness to contribute to their communities.

The study findings point to existing datasets that may be implicated in an intersectional approach to provide a more nuanced understanding of what determines individual young people's life strategies and defines their decisions to stay or leave. Among social categories that can be used for the intersectional analysis of youth migration, the study identified gender, age, Indigeneity, and socioeconomic status.

Gender is an important factor informing young people's career and life strategies. For instance, in the sphere of career preferences, the study revealed gender differences that reflect the structural peculiarities of the Arctic economies across the Circumpolar North $[2,69,70,91-93]$. Despite a general persistent trend over recent decades of the feminization of human capital (the gap between women with higher attainment in educational credentials and less educated men is increasing) in most Arctic regions $[70,88,94]$, survey findings also show that in NAO and YaNAO, female students may find themselves in a path dependency situation. For instance, females often consider education, medicine, and the government sector among their top spheres. The surveys also identified that gender-related imposed choices of occupations are more prevalent among females. Male students' choices were also limited to male-dominated economic sectors, as they view the oil and gas industries, IT, transportation and construction, and reindeer husbandry (among Indigenous students) as the most attractive professions. On the one hand, young people find themselves in a situation of the Arctic's prevalent gender-based occupational clustering $[69,70,91-93]$. On the other hand, their professional choices make this system even more entrenched.

Age can be a determining factor for out-migration. In this research, the number of those willing to stay in the region grew with increasing age of the respondents: representatives of the youngest age group of high school students (14 to 17 y.o.) are mostly inclined to relocate, while vocational college students' (17-21 y.o.) life strategies vary.

Indigeneity identifies different approaches in life strategizing among Indigenous and non-Indigenous youth. In the Arctic countries, the ability of Indigenous people to access 
institutions of higher learning, while improving, is still problematic [88] (pp. 381-383; 387-389) [95-97]. In the education market, Indigenous young people face a lack of affordable, diverse educational opportunities, outside the scope of "traditional" professions available to them in local vocational schools and colleges. Limited in their career choices, female respondents focus on career building in a more traditional female domain (i.e., primary education, medicine, culinary arts, culture). Their choices of occupations in the cultural sphere may also be related to the legacy of the Soviet times, with government support of the Indigenous cultural economy and traditional activities in the Arctic, which provides some employment opportunities in specially created niches and, to some degree, reduces the competition for Indigenous youth [79]. At the same time, male students are often trapped in the male domain or follow their Indigenous path by choosing professions such as auto mechanics, drivers, reindeer breeders, etc.

The socioeconomic status category is related to the socioeconomic disparity in the focal regions and exposes the gap between students from relatively wealthy families with enough funds to send out their children to the universities and those families that lack financial means and whose children (have to or choose to) stay in their Arctic communities with few chances for career development, economic independence, and empowerment [73]. In the case of the Indigenous youth, although their stay improves the social sustainability indicator related to the component of migration and residential stability (vs. turnover) and makes them true stewards of Arctic lands, this existing gap in life opportunities and strategies of Indigenous vs. non-Indigenous students reveals a significant inequality in Arctic communities.

Based on these research findings, the Arctic communities face tremendous risks associated with youth "flight", making their future social sustainability uncertain. To retain young people or to attract them (back) to the Arctic [94,98], heavy investments in human capital and structural changes in the economy are inevitable. The necessity of Arctic university and research centers as a point of local youth attraction and development of a knowledge-based economy [99] in the Arctic has been recognized and implemented by many governments in the Circumpolar region (Canada, Iceland, Greenland and Faroe Islands, Finland, Norway, USA, and in some Arctic regions of Russia). In our two study regions, it is still in the distant future: While the NAO government included the establishment of a university branch in the NAO Strategy 2030 [5], in the YaNAO Strategy 2035 [6], a university is not even mentioned, leaving fewer chances for well-being and prosperity for local young people.

\section{Conclusions}

Using the example of the three Northern indicative cities of Naryan-Mar, Salekhard, and Novy Urengoy, the study examined key components of social sustainability primarily based on ISO 37120, complementing statistical information and analytical data with survey results. The study identified preponderant factors that to a large extent determine the local youth's life strategizing and define their decisions to stay or leave, which ultimately may affect social (socioeconomic) sustainability in these regions. Among the key factors are: (1) limited educational opportunities and lack of higher education institutions; (2) a limited range of high-quality jobs available for local youth in a highly competitive labor market for high-, semi-, and low-skilled workers; (3) limited opportunities for cultural and leisure activities; and (4) a low level of youth engagement in community services and the voluntary sector, revealing young people's low attachment to place $[89,98,100]$.

From a broader perspective, the life strategies of the young generation of Northerners in Russia and their individual choices to stay in their Arctic communities or leave are a part of significant migration trends and patterns in the Circumpolar North [29-36]. In many Arctic countries, the prevalence of a psychological mood for out-migration among the local young people $[29,101]$ puts them in a position where they are "stuck between their dreams and what they feel is realizable" [29] (p. 46) or move away seeking a way out. 
The three Russian Arctic cities of Naryan-Mar, Salekhard, and Novy Urengoy showcase how insufficient investment in human and social capital, particularly relevant to the cohort of young people (e.g., through good educational and community facilities and wider employment opportunities for local youth), creates communities where local youth feel disempowered and pessimistic about their futures in the Arctic. The youth survey's findings on education, employment opportunities, and leisure time structure demonstrate that a majority of high school and vocational students view educational out-migration as a necessary condition for them to fulfill their dreams and realize their ambitions.

By analyzing survey results in the broader socioeconomic contexts of NAO and $\mathrm{YaNAO}$, this article argues that Arctic regional economic prosperity, even in times of high and long-lasting demand for natural resources on the global market, does not necessarily benefit the locals, particularly the youth, nor lead to the social sustainability of Arctic communities. The combination of factors such as industrialization boom and economic 'bonanza' can serve to depict one of many Arctic paradoxes: Growing industries create new jobs and career opportunities that mostly fit and benefit not locals but rather newcomers and FIFO workers and, in turn, trigger young residents' out-migration and increase vulnerabilities in local communities. One can observe here a dilemma that is common for many remote Arctic areas where young individuals' self-interests often conflict with the overall common good for society and communities' social sustainability: "while a community may suffer from out-migration, individuals relocating elsewhere may experience an improvement in their quality of life" [102] (p. 62).

To improve the situation of the out-migration of young people, it is necessary to move Arctic youth from the periphery to the center of public policy discourse and decision making. This may include political actions to be taken in terms of prioritizing the provision of high-quality professional training programs and higher educational opportunities, providing greater investments in diverse social and cultural infrastructure, and implementing prioritization of youth-oriented affirmative action policies (e.g., quotas) for employing local youth in the labor market. Last but not least, the engagement of young people in defining problems and drawing up policies is vital to allow younger generations to have control over their own futures in the Arctic and responsibility for the future and social sustainability of their communities.

\section{Limitations and Future Directions}

The research was limited to three focal Arctic cities and did not include other Russian Arctic regions with university centers experiencing a youth flight. The lack of comprehensive statistical data on "city-to-city" and return migration limited the scope of analysis. A lack of relevant socioeconomic data did not allow the author to connect social sustainability indicators, governmental programs, laws and regulations, and industry and non-governmental sector initiatives with youth development trends. A non-probability sampling method was used for the youth survey due to limited access to students in educational institutions. The research conclusions may also be limited as not all dimensions of diversity (e.g., gender, ethnicity, Indigeneity) were addressed in the youth survey, which did not allow the study to utilize an intersectional approach. To ensure that the study posed no risks for the student participants, the questionnaires did not include the central topic of political engagement of the youth and structural barriers to empowerment. Future research will close some of these gaps.

Funding: This research was funded by NSF (Program for International Research and Education project "Promoting Urban Sustainability in the Arctic" (PIRE)), award number 1545913.

Institutional Review Board Statement: Approved by the RSHU.

Informed Consent Statement: Informed consent was obtained from all subjects involved in this study.

Data Availability Statement: Not applicable. 
Acknowledgments: I would like to thank Marlene Laruelle (GWU), Robert Orttung (GWU), and Andrey N. Petrov (ARCTICenter, UNI) for conceptual advice on this article and support of the field research in the Nenets and Yamalo-Nenets Autonomous Regions as part of the Program for International Research and Education (PIRE) project "Promoting Urban Sustainability in the Arctic" (NSF Award \#1545913). My deep appreciation goes to Nadezda Zmyatina (MSU) for her valuable consultation on the focal Arctic cities. Special thanks go to the Russian State Hydrometeorological University (RSHU) for its valuable organizational support of this fieldwork, and especially to its Rector, Valeriy L. Mikheev. I would further like to express my deep gratitude to all study participants in Naryan-Mar, Salekhard, and Novy Urengoy who shared their career plans, hopes, and concerns. Finally, my deep appreciation goes to Zoe Garbis (GWU) for copy editing, Pauline Mnev (GWU) for designing the map of the study site, and the three anonymous reviewers for their highly valuable comments and great ideas for future research directions.

Conflicts of Interest: The author declares no conflict of interest.

\section{Appendix A}

Table A1. Urban sustainability indicators relevant to Arctic youth.

\begin{tabular}{|c|c|c|c|c|}
\hline № & Indicator & Naryan-Mar & Salekhard & Novy Urengoy \\
\hline \multicolumn{5}{|c|}{ Demographics } \\
\hline 13.4 .3 & Percentage of population who are youths (15-24 y.o.) & 9.5 & 9.5 & 10.4 \\
\hline \multicolumn{5}{|c|}{ Economics } \\
\hline 5.4 * & Youth unemployment rate & 4.7 & 3.7 & 3.7 \\
\hline $5.5^{*}$ & Number of businesses per 100,000 population & 3590 & 2610 & 2410 \\
\hline ** & $\begin{array}{l}\text { Employment in cultural sphere (as a percentage of } \\
\text { total employed) }\end{array}$ & 4.6 & 4.7 & 1.3 \\
\hline \multicolumn{5}{|c|}{$\begin{array}{ll}\text { Education } \\
\end{array}$} \\
\hline $6.6^{*}$ & $\begin{array}{l}\text { Number of higher education degrees per } 100,000 \\
\text { population }\end{array}$ & 46,812 & 37,529 & 37,360 \\
\hline$\&$ & Number of universities in the city & 0 & 0 & 0 \\
\hline \multicolumn{5}{|c|}{ Cultural, Sporting, and EntertainmentInfrastructure } \\
\hline $17.1^{* * *}$ & $\begin{array}{c}\text { Number of cultural institutions and facilities per } \\
100,000 \text { population (modified indicator) }\end{array}$ & 28 & 22 & 17.2 \\
\hline $17.1^{* * *}$ & $\begin{array}{l}\text { Number of sporting facilities per } 100,000 \text { population } \\
\text { (modified indicator) }\end{array}$ & 217.5 & 191.8 & 259 \\
\hline$\&$ & $\begin{array}{l}\text { Number of restaurants, bars, cafes, and fast food } \\
\text { restaurants per } 100,000 \text { population }\end{array}$ & 123.2 & 94.2 & 91.5 \\
\hline$\&$ & $\begin{array}{l}\text { Number of seats available at restaurants, bars, cafes, } \\
\text { and fast food restaurants per } 100,000 \text { population }\end{array}$ & 6528 & 4161 & 5756 \\
\hline$\&$ & Number of public caterings per 100,000 population & 31.8 & 15.7 & 49.13 \\
\hline$\&$ & $\begin{array}{l}\text { Number of seats available at public caterings per } \\
\qquad 100,000 \text { population }\end{array}$ & 4898 & 2356 & 3829 \\
\hline
\end{tabular}

\section{Contribution to Civil Society}

\begin{tabular}{cccc}
\hline$\& \quad \begin{array}{c}\text { Number of youths participating in volunteer } \\
\text { activities per 100,000 population }\end{array}$ & $\mathrm{n} / \mathrm{a}$ & $\mathrm{n} / \mathrm{a} / \mathrm{a}$ \\
\hline & Political Empowerment \\
\hline$\& \quad \begin{array}{c}\text { Number of young adult deputies (18-35 y.o.) elected } \\
\text { in the City Council per 100,000 population }\end{array}$ & 0 & 1.96 \\
\hline
\end{tabular}

* PIRE's indicator; ${ }^{* *}$ Based on methodology by Vera Kuklina and Natalia Shishigina [80]; ${ }^{* *}$ Modified indicator. In the framework of the ISO 37120 methodology, cultural institutions and sporting facilities are not separated. \& The author's indicator. 


\section{References}

1. Hill, F.; Gaddy, C. The Siberian Curse: How Communist Planners Left Russia Out in the Cold; Brookings Institution Press: Washington, DC, USA, 2003.

2. Larsen, J.N.; Petrov, A.N. The Economy of the Arctic. In The Palgrave Handbook of Arctic Policy and Politics; Coates, K., Holroyd, C., Eds.; Palgrave Macmillan: Cham, Switzerland, 2020. [CrossRef]

3. Federal State Statistics Service. Available online: https:/ / eng.rosstat.gov.ru/ (accessed on 16 July 2021).

4. Ministry of Economic Development of the Russian Federation. Program on Energy Efficiency and Energy Development in Nenets Autonomous Okrug (No. 229-p, 12 July 2017); Administration of the Nenets Autonomous Okrug: Naryan-Mar, Russia, 2017.

5. Ministry of Economic Development of the Russian Federation. The Strategy of Socio-Economic Development of the Nenets Autonomous Okrug until 2030 (No. 256-sd, 7 November 2019); Administration of the Nenets Autonomous Okrug: Naryan-Mar, Russia, 2019.

6. Ministry of Economic Development of the Russian Federation. The Strategy of Socio-Economic Development of the Yamalo-Nenets Autonomous Okrug until 2035 (No. 478, 24 June 2021); Administration of the Yamalo-Nenets Autonomous Okrug: Salekhard, Russia, 2021.

7. Petrov, A.; Vlasova, T. Migration and socio-economic well-being in the Russian North: Interrelations, regional differentiation, recent trends and emerging issues. In Migration in the Circumpolar North: New Concepts and Patterns; Huskey, L., Southcott, C., Eds.; CCI Press: Edmonton, AB, Canada, 2010; pp. 163-192.

8. Rosstat, Arkhangelsk. Available online: https://arhangelskstat.gks.ru/ (accessed on 12 January 2021).

9. Rosstat. The Russian Census of 2010. Available online: https:/ / eng.rosstat.gov.ru/folder/76215 (accessed on 8 September 2020).

10. Yarlykapov, A. Divisions and Unity of the Novy Urengoy Muslim Community. Probl. Post-Communism 2020, 67, 338-347. [CrossRef]

11. Rosstat. Regiony Rossii. Sotsial'no-Ekonomicheskiye Pokazateli; Rosstat: Moscow, Russia, 2019. Available online: https://rosstat.gov. $\mathrm{ru}$ /accounts (accessed on 4 June 2021).

12. Sergunin, A. Planning for Sustainability: The Russian Case. In Urban Sustainability in the Arctic: Measuring Progress in Circumpolar Cities; Orttung, R., Ed.; Berghan Books: New York, NY, USA; Oxford, UK, 2020; pp. 228-252.

13. Orttung, R. Conclusion. Next Steps for Measuring Arctic Urban Sustainability In Urban Sustainability in the Arctic: Measuring Progress in Circumpolar Cities; Orttung, R., Ed.; Berghan Books: New York, NY, USA; Oxford, UK, 2020; pp. $278-288$.

14. Petrov, A.N. Human Capital and Sustainable Development in the Arctic: Towards Intellectual and Empirical Framing. In Northern Sustainabilities: Understanding and Addressing Change in the Circumpolar World; Springer International Publishing: Cham, Switzerland, 2017; pp. 203-220. [CrossRef]

15. Petrov, A.; BurnSilver, S.; Chapin, T.; Fondahl, G.; Graybill, J.; Keil, K.; Nilsson, A.; Riedlspieger, R.; Schweitzer, P. Arctic Sustainability Research: A White Paper for the International Conference on Arctic Research Planning III (ICARP III). Summary and Findings. 2016. Available online: http://icarp.iasc.info/images/articles/Themes/WP_Summary_Sustainability_science_ ICARP3_draft1.pdf (accessed on 2 July 2021).

16. Fondahl, G.; Wilson, G.N. Exploring Sustainabilities in the Circumpolar North. In Northern Sustainabilities: Understanding and Addressing Change in the Circumpolar World; Springer International Publishing: Cham, Switzerland, 2017; pp. 1-9. [CrossRef]

17. Partridge, E. Social Sustainability. In Encyclopedia of Quality of Life and Well-Being Research; Michalos, A.C., Ed.; Springer: Berlin/Heidelberg, Germany, 2014; p. 6178.

18. Colantonio, A. Traditional and Emerging Prospects in Social Sustainability. Measuring Social Sustainability: Best Practice from Urban Renewal in the EU; 2008/02: EIBURS Working Paper Series; November 2008; Oxford Institute for Sustainable Development (OISD): Oxford, UK, 2008.

19. Omann, I.; Spangenberg, J.H. Assessing social sustainability. The social dimension of sustainability in a socio-economic scenario. In Proceedings of the 7th Biennial Conference of the International Society for Ecological Economics, Sousse, Tunisia, 6-9 March 2002.

20. Dempsey, N.; Bramley, G.; Power, S.; Brown, C. The social dimension of sustainable development: Defining urban social sustainability. Sustain. Dev. 2009, 19, 289-300. [CrossRef]

21. Office of the Deputy Prime Minister (ODPM). UK Presidency: EU Ministerial Informal on Sustainable Communities Policy Papers; ODPM: London, UK, 2005.

22. Fujita, M.; Krugman, P.; Venables, A.J. The Spatial Economy: Cities, Regions, and International Trade; MIT Press: Cambridge, MA, USA, 1999.

23. Zamyatina, N.; Goncharov, R. Arctic Urbanization: Resilience in a Condition of Permanent Instability: The Case of Russian Arctic Cities. In Resilience and Urban Disasters: Surviving Cities; Borsekova, K., Nijkamp, P., Eds.; Edward Elgar: Cheltenham, UK, 2018; pp. 136-154.

24. Laruelle, M. Russia's Arctic Strategies and the Future of the Far North; M. E. Sharpe: Armonk, NY, USA; London, UK, 2014.

25. Kravale-Paulina, M.; Olehnoviča, E.; Ostrovska, I.; Ivanova, A.; Šipilova, V. Youth Policy Monitoring as a Tool for Developing Social Sustainability in Local Municipality. Probl. Educ. 21st Century 2008, 76, 350-363. [CrossRef]

26. Boström, M. A missing pillar? Challenges in theorizing and practicing social sustainability: Introduction to the special issue. Sustain. Sci. Pract. Policy 2012, 8, 3-14. [CrossRef]

27. European Investment Bank. The Charter of European Sustainable Cities and Towns Towards Sustainability. 2005. Available online: https:/ / www.eib.org/attachments/jessica_bristol_accord_sustainable_communities.pdf (accessed on 13 February 2021). 
28. Laruelle, M. Assessing Social Sustainability. Immigration to Russia's Arctic cities. In Sustaining Russia's Arctic Cities. Resource Politics, Migration, and Climate Change; Orttung, R., Ed.; Berghan Books: New York, NY, USA; Oxford, UK, 2017 ; pp. 88-111.

29. Karlsdóttir, A.; Jungsberg, L. (Eds.) Nordic Arctic Youth Future Perspectives; Nordregio Working Paper 2015:2; Nordregio: Stockholm, Sweden, 2015.

30. Pedersen, B.K. Young Greenlanders in the urban space of Nuuk. Études Inuit Studies 2008, 32, 91-105. [CrossRef]

31. Rygaard, J. The city life of youths in Greenland. Études Inuit Studies 2008, 32, 33-54. [CrossRef]

32. Hamilton, L.; Rasmussen, R.O. Population, sex ratios and development in Greenland. Arctic 2010, 63, 43-52. [CrossRef]

33. Carson, D.; Rasmussen, R.O.; Ensign, P.; Huskey, L.; Taylor, A. (Eds.) Demography at the Edge: Remote Human Populations in Developed Nations; Ashgate: Burlington, VT, USA, 2011.

34. Rasmussen, R.O. Polar Women Go South. J. Nordregio 2007, 7, 20-22.

35. Taylor, A.J. Current evidence of 'female flight' from remote Northern Territory Aboriginal communities-Demographic and policy implications. Migr. Lett. 2011, 8, 77-89. [CrossRef]

36. Hamilton, L. Footprints: Demographic Effects of Out-Migration. In Migration in the Circumpolar North: Issues and Contexts; Huskey, L., Southcott, C., Eds.; Canadian Circumpolar Institute: Edmonton, AB, Canada, 2010; pp. 1-14.

37. Bolotova, A.; Karaseva, A.; Vasilyeva, V. Mobility and Sense of Place among Youth in the Russian Arctic. Sibirica 2017, 16, 77-123. [CrossRef]

38. Osipova, O.V.; Maklashova, E.G. Migration intentions of the Arctic youth in the context of subjective evaluations of the social wellbeing. Arct. North 2016, 24, 13-24. [CrossRef]

39. Osipova, O.; Maklashova, E. Molodezh' Arktiki: Migratsionnyye namereniya i sotsial'nyye ozhidaniya. J. Sib. Far East. Stud. 2014, 10, 6-44.

40. Petrov, A.N.; Korkina, V.V.; Vlasova, T.K.; Rozanova, M.S.; Ulturgasheva, A. Arctic Youth from Russia. In Arctic Youth and Sustainable Futures; Larsen, J.N., Ingimundarson, J.H., Eds.; Nordic Council of Ministers: Copenhagen, Denmark, 2022; Forthcoming.

41. Bolotova, A. Living or Leaving? Youth and the Liveability of Single-industry Towns in the Russian Arctic. Available online: https:/ / www.helsinki.fi/sites/default/files/atoms/files/ai-2-20-netti.pdf (accessed on 2 February 2021).

42. International Organization for Standardization. Sustainable Cities and Communities—Indicators for City Services and Quality of Life. 37101:2016. Available online: https:/ / www.iso.org/standard/61885.html (accessed on 2 October 2020).

43. Rasmussen, R.O.; Roto, J.; Hamilton, L.C. West-Nordic Region. In Arctic Social Indicators: ASI II: Implementation; Larsen, J.N., Schweitzer, P., Petrov, A., Eds.; Nordic Council of Ministers: Copenhagen, Denmark, 2004; pp. 155-209.

44. Mkrtchyan, N.V. Problemy v statistike vnutrirossiyskoy migratsii, porozhdennyye izmeneniyem metodiki ucheta v $2011 \mathrm{~g}$ Demogr. Obozr. 2020, 7, 83-99.

45. Zamyatina, N.Y.; Yashunsky, A.D. Virtual geography of virtual population. Monit. Public Opin. Econ. Soc. Chang. 2018, 143, 117-137. [CrossRef]

46. Heleniak, T. Arctic Populations and Migration. In Arctic Human Development Report: Regional Processes and Global Linkages; Larsen, J.N., Fondahl, G., Eds.; Nordic Council of Ministers: Copenhagen, Denmark, 2004; pp. 53-104.

47. Heleniak, T. Where Did All the Men Go? The Changing Sex Composition of the Russian North in the Post-Soviet Period, 1989-2010. Polar Rec. 2019. [CrossRef]

48. Kashnitsky, I.; Mkrtchyan, N.; Leshukov, O. Interregional Migration of Youths in Russia: A Comprehensive Analysis of Demographic Statistics. Vopr. Obraz./Educ. Stud. Mosc. 2016, 169-203. [CrossRef]

49. Konyshev, V.N.; Sergunin, A.A.; Subbotin, S.V. Sotsial'naya mobil'nost' v rossiyskoy Arktike [Social mobility in the Russian Arctic]. Natsional'nye interesy prioritety i bezopasnost' [Natl. Interests Priorities Secur.] 2017, 13, 1189-1196. (In Russian) [CrossRef]

50. Zamyatina, N.; Yashunsky, A. Migration cycles, social capital, and networks: A new way to look at Arctic mobility. In New Mobilities and Social Changes in Russia's Arctic Regions; Laruelle, M., Ed.; Routledge: London, UK; New York, NY, USA, 2017; pp. 59-84.

51. Appendix "Strategy of Socio-Economic Development of the Municipal Formation of the City of Novy Urengoy until 2030". Available online: http:/ / www.newurengoy.ru/docs/15603-strategiya-socialno-ekonomicheskogo-razvitiya-municipalnogoobrazovaniya-gorod-novyy-urengoy-do-2030-goda.html (accessed on 14 September 2020).

52. The Strategy of Social and Economic Development of the City of Salekhard until 2030s. Available online: https://www.salekhard. $\mathrm{org} /$ city/socs/strategiya-razvitiya-mo/ (accessed on 14 September 2020).

53. On Approval of the Strategy of Socio-Economic Development of the Nenets Autonomous Okrug until 2030. Available online: http:/ / docs.cntd.ru/document/561620008 (accessed on 14 September 2020).

54. Laruelle, M. Introduction. In New Mobilities and Social Changes in Russia's Arctic Regions; Laruelle, M., Ed.; Routledge: London, UK; New York, NY, USA, 2017.

55. Ivo, J.H.B.; Stephen, J.D.H.; Svein, G. What's next for Big Oil. In McKinsey Quarterly; What Global Executives Think about Growth \& Risk; McKinsey: New York, NY, USA, 2005.

56. Tysiachniouk, M.S. Disentangling Benefit-Sharing Complexities of Oil Extraction on the North Slope of Alaska. Sustainability 2020, 12, 5432. [CrossRef]

57. Nuykina, Y.V. Vliyaniye vakhtovogo metoda raboty na prinimayushchiye goroda Rossiyskogo Severa (na primere goroda Vorkuty). Izvestiya Komi nauchnogo tsentra URO RAN 2013, 2, 107-116. 
58. Berman, M.; Loeffler, R.; Schmidt, J.I. Long-term benefits to Indigenous communities of extractive industry partnerships: Evaluating the Red Dog Mine. Resour. Policy 2020, 66, 101609. [CrossRef]

59. Tysiachniouk, M.; Andrey, N.P.; Vera, K.; Natalia, K. Between Soviet Legacy and Corporate Social Responsibility: Emerging Benefit Sharing Frameworks in the Irkutsk Oil Region, Russia. Sustainability 2018, 10, 3334. [CrossRef]

60. Sokolov, D. Ugra, the Dagestani North: Anthropology of mobility between the North Caucasus and western Siberia. In New Mobilities and Social Changes in Russia's Arctic Regions; Laruelle, M., Ed.; Routledge: London, UK; New York, NY, USA, 2017; pp. 176-193.

61. Kulik, S.; Eidemiller, K. K voprosu ob islamskom regionalizme v Arkticheskoi zone RF. In Arktika: Istoriya i Sovremennost': Trudy Mezhdunarodnoi Nauchnoi Konferentsii, St. Peterburg, Russia, 20-21 April 2016; Kulik, S.V., Ed.; Izdatel'skii Dom “Nauka": Moscow, Russia, 2016.

62. Oparin, D. Locals and immigrants on the Yamal Peninsula. Social boundaries and variations in migratory experience. Asian Ethn. 2018, 19, 251-269. [CrossRef]

63. Law of the Nenets Autonomous Okrug, 8 November 2016, № 246-OZ «O kvotirovanii Rabochikh mest dlya otdel'nykh Kategoriy Grazhdan v Nenetskom Avtonomnom Okruge»; Assembly of Deputies of the Nenets Autonomous Okrug: Naryan-Mar, Russia, 2016.

64. NAO Official Website. Traditsionnaya Tseremoniya Posvyashcheniya v Neftyaniki Uchenikov «Rosneft'-Klassa» Sostoyalas' v Posolke Iskateley. 14 September 2019. Available online: http://adm-nao.ru/press/governor/22256/ (accessed on 14 September 2020).

65. Interfax. Putin podderzhal ideyu Tselevogo Obucheniya Predstaviteley Malochislennykh Narodov Kraynego Severa. 29 November 2019. Available online: https:/ / academia.interfax.ru/ru/news/articles/3902 (accessed on 19 September 2020).

66. Interfax. V Rossii Budet Sozdana Organizatsiya po Realizatsii Gosudarstvennoy Natsional'noy Politiki. 20 January 2020. Available online: https:/ / www.interfax-russia.ru/moscow/news/v-rossii-budet-sozdana-organizaciya-po-realizacii-gosudarstvennoynacionalnoy-politiki (accessed on 4 January 2021).

67. Decree of the Government of the Yamalo-Nenets Autonomous Okrug of 12 December 2018, N 1661-R On approval of the comprehensive program "Sustainable development of indigenous peoples of the North in the Yamalo-Nenets Autonomous Okrug for 2018-2022". Available online: https:/ / docs.cntd.ru/document/550269204 (accessed on 17 December 2020).

68. Ross, M.L. The Oil Curse: How Petroleum Wealth Shapes the Development of Nations; Princeton University Press: Princeton, NJ, USA, 2012.

69. Malgorzata, S.; Prior, T. Gender and Environment. In Gender Equality in the Arctic; Oddsdóttir, E., Ágústsson, H.O., Eds.; Icelandic Ministry for Foreign Affairs: Reykjavik, Iceland, 2021; pp. 98-143.

70. Rozanova-Smith, M.; Petrov, A.; Williams, V.K. Empowerment and Fate Control. In Gender Equality in the Arctic; Oddsdóttir, E., Ágústsson, H.O., Eds.; Icelandic Ministry for Foreign Affairs: Reykjavik, Iceland, 2021; pp. 224-267.

71. Website "Moi Biznes YaNAO". Available online: http:/ / mb89.ru/news/ofitsialno/na-yamale-vpervye-sostoitsya-proekt-mamapredprinimatel-/ (accessed on 2 January 2021).

72. Website "Ministerstvo Ekonomicheskogo Razvitiya Rossiyskoy Federatsii". Available online: http://nko.economy.gov.ru/ PortalNews/Read/5109 (accessed on 2 January 2021).

73. Decree of the Government of the Russian Federation of 21 November 2007, N 1661-R <On the Concept of the Federal Target Program "Economic and Social Development of the Indigenous Peoples of the North, Siberia, and the Far East until 2015".> (Chapter 3). Available online: http://www.consultant.ru/document/cons_doc_LAW_136920/(accessed on 29 August 2020).

74. Program for International Research and Education Project "Promoting Urban Sustainability in the Arctic (PIRE), ISO 5.4 Indicator. Available online: http://blogs.gwu.edu/arcticpire/project-publications/data/ (accessed on 23 October 2020).

75. Reisser, C. Russia's Arctic Cities: Recent Evolution and Drivers of Change. In Sustaining Russia's Arctic Cities: Resource Politics, Migration, and Climate Change; Orttung, R., Ed.; Berghahn: New York, NY, USA, 2016; pp. 1-22.

76. Lishchuk, Y.N.; Kapelyuk, S.D. Problemy regulirovaniya oplaty truda rabotnikov Kraynego Severa i priravnennykh k nemu mestnostey. Ekonomika 2020, 16, 97-113. [CrossRef]

77. Volgin, N.A.; Shirokova, L.N.; Mosina, L.L. Aktual'nyye voprosy razvitiya rossiyskogo severa: Kompensatsionnyye i stimuliruyushchiye sistemy. Uroven' zhizni Naseleniya Regionov Rossii 2018, 2, 34-46. [CrossRef]

78. Novikova, I.V. Perspektivy ispol'zovaniya dal'nevostochnykh garantiy gosudarstva kak instrumenta sodeystviya zanyatosti naseleniya v regione. Uroven' zhizni Naseleniya Regionov Rossii 2016, 1, $206-219$.

79. Rozanova, M. Indigenous Urbanization in Russia's Arctic: The Case of Nenets Autonomous Region. Sibirica. J. Sib. Stud. 2019, 18, 54-91.

80. Kuklina, V.; Shishigina, N. Yakutsk: Culture for Sustainability. In Urban Sustainability in the Arctic: Measuring Progress in Circumpolar Cities; Orttung, R., Ed.; Berghan Books: New York, NY, USA; Oxford, UK, 2020; pp. 101-128.

81. Government of NAO. Available online: http://smi.adm-nao.ru/otnosheniya-v-nao/sociologicheskoe-issledovanieobshestvennogo-mneniya-po-voprosam-toler/ (accessed on 2 August 2020).

82. Laruelle, M. Postcolonial Polar Cities? New Indigenous and Cosmopolitan Urbanness in the Arctic. Acta Borealia 2019, 36, 149-165. [CrossRef]

83. Laruelle, M. Urban Regimes in Russia's Arctic Cities: Testing a Concept in a New Environment. Arctic 2020, 73, 53-66. [CrossRef]

84. YaNAO Library. Available online: http://nb.yanao.ru/\#top (accessed on 2 August 2020).

85. Khakhovskaya, L. Aborigeny v gorode: Etnokul'turnyi oblik zhitelei Magadana. Sibirskie Istoricheskie Issledovaniia 2004, 2, 39-59. 
86. Keyes, C.L.M. Social well-being. Soc. Psychol. Q. 1998, 61, 121-140. [CrossRef]

87. Gudkov, L.; Zorkaya, N.; Kochergina, E.; Pipiya, K.; Ryseva, A. Russia's 'Generation Z': Attitudes and Values 2019/2020; Chekhov Printing House: Moscow, Russia, 2020; Available online: http:/ /library.fes.de/pdf-files/bueros/moskau/16134.pdf (accessed on 11 November 2020).

88. Hirshberg, D.; Petrov, A. Education and Human Capital. In Arctic Human Development Report: Regional Processes and Global Linkages; Nordisk Ministerråd: Copenhagen, Denmark, 2015.

89. De Dominicis, S.; Fornara, F.; Ganucci Cancellieri, U.; Twigger-Ross, C.; Bonaiuto, M. We are at risk, and so what? Place attachment, environmental risk perceptions and preventive coping behaviours. J. Environ. Psychol. 2015, 43, 66-78. [CrossRef]

90. Bramley, G.; Morgan, J. Building competitiveness and cohesion: The role of new housebuilding in central Scotland's cities. Hous. Stud. 2003, 18, 447-471. [CrossRef]

91. Ashwin, S. Adapting to Russia's New Labour Market: Gender and Employment Behaviour; Routledge: London, UK, 2006.

92. Novikova, S.S. Social state and gender equality in modern Russia. Contemp. Probl. Soc. Work. 2016, 2, 72-78. [CrossRef]

93. Oddsdóttir, E.; Sigurðsson, A.M.; Svandal, S. (Eds.) Gender Equality in the Arctic: Current Realities, Future Challenges; Icelandic Ministry for Foreign Affairs: Reykjavik, Iceland, 2015.

94. Rasmussen, R.O. (Ed.) Megatrend; Nordic Council of Ministers: Copenhagen, Denmark, 2011.

95. Stonechild, B. The New Buffalo: The struggle for Aboriginal post-secondary education in Canada; University of Manitoba Press: Winnipeg, MB, USA, 2006.

96. Preston, J.P. The urgency of postsecondary education for Aboriginal peoples. Can. J. Educ. Adm. Policy 2008, 86, 1-22.

97. Rasmussen, R.O.; Barnhardt, R.; Keskitalo, J.H. Education. In ASI I, 2010. Arctic Social Indicators-a follow-up to the Arctic Human Development Report; Larsen, J.N., Schweitzer, P., Fondahl, G., Eds.; TemaNord. Nordic Council of Ministers: Copenhagen, Denmarks, 2010; pp. 67-90.

98. Heleniak, T. The role of attachment to place in migration decisions of the population of the Russian North. Polar Geogr. 2009, 32, 31-60. [CrossRef]

99. Temple, P. (Ed.) Universities in the Knowledge Economy: Higher Education Organisation and Global Change; Routledge: London, UK, 2012.

100. Tuhkunen, A. Between Location and a Sense of Place Observations Regarding Young People's Migra-tion Alacrity in Northern Europe; University of Tampere Publ.: Tampere, Finland, 2007.

101. Hayfield, E.A.; Aure, M.; Barillé, S.; Farrell, C.R.; Gaini, F.; Gerrard, S.; Gotfredsen, A.; Gram-Hanssen, I.; Hamilton, L.; Hoffmann, L.W.; et al. Migration and Mobility. In Gender Equality in the Arctic; Oddsdóttir, E., Ágústsson, H.O., Eds.; Icelandic Ministry for Foreign Affairs: Reykjavik, Iceland, 2021; pp. 144-191.

102. Fondahl, G.; Crate, S.; Filippova, V.V. Sakha Repubic (Yakutia), Russian Federation. In Arctic Social Indicators: ASI II: Implementation; Larsen, J.N., Schweitzer, P., Petrov, A., Eds.; Nordic Council of Ministers: Copenhagen, Denmarks, 2014; pp. 57-91. 